\title{
Aerosol and precipitation chemistry in the southwestern United States: spatiotemporal trends and interrelationships
}

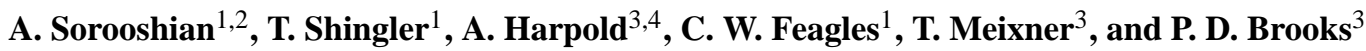 \\ ${ }^{1}$ Department of Chemical and Environmental Engineering, University of Arizona, Tucson, Arizona, USA \\ ${ }^{2}$ Department of Atmospheric Sciences, University of Arizona, Tucson, Arizona, USA \\ ${ }^{3}$ Department of Hydrology and Water Resources, University of Arizona, Tucson, Arizona, USA \\ ${ }^{4}$ Institute of Arctic and Alpine Research, University of Colorado Boulder, Boulder, Colorado, USA
}

Correspondence to: A. Sorooshian (armin@email.arizona.edu)

Received: 18 February 2013 - Published in Atmos. Chem. Phys. Discuss.: 2 April 2013

Revised: 14 June 2013 - Accepted: 24 June 2013 - Published: 1 August 2013

\begin{abstract}
This study characterizes the spatial and temporal patterns of aerosol and precipitation composition at six sites across the United States Southwest between 1995 and 2010. Precipitation accumulation occurs mostly during the wintertime (December-February) and during the monsoon season (July-September). Rain and snow pH levels are usually between 5-6, with crustal-derived species playing a major role in acid neutralization. These species $\left(\mathrm{Ca}^{2+}, \mathrm{Mg}^{2+}, \mathrm{K}^{+}, \mathrm{Na}^{+}\right)$ exhibit their highest concentrations between March and June in both $\mathrm{PM}_{2.5}$ and precipitation due mostly to dust. Crustalderived species concentrations in precipitation exhibit positive relationships with $\mathrm{SO}_{4}^{2-}, \mathrm{NO}_{3}^{-}$, and $\mathrm{Cl}^{-}$, suggesting that acidic gases likely react with and partition to either crustal particles or hydrometeors enriched with crustal constituents. Concentrations of particulate $\mathrm{SO}_{4}^{2-}$ show a statistically significant correlation with rain $\mathrm{SO}_{4}^{2-}$ unlike snow $\mathrm{SO}_{4}^{2-}$, which may be related to some combination of the vertical distribution of $\mathrm{SO}_{4}^{2-}$ (and precursors) and the varying degree to which $\mathrm{SO}_{4}^{2-}$-enriched particles act as cloud condensation nuclei versus ice nuclei in the region. The coarse : fine aerosol mass ratio was correlated with crustal species concentrations in snow unlike rain, suggestive of a preferential role of coarse particles (mainly dust) as ice nuclei in the region. Precipitation $\mathrm{NO}_{3}^{-}: \mathrm{SO}_{4}^{2-}$ ratios exhibit the following features with potential explanations discussed: (i) they are higher in precipitation as compared to $\mathrm{PM}_{2.5}$; (ii) they exhibit the opposite annual cycle compared to particulate $\mathrm{NO}_{3}^{-}: \mathrm{SO}_{4}^{2-}$ ratios; and (iii) they are higher in snow relative to rain during the wintertime. Long-term trend analysis for the monsoon season shows that the $\mathrm{NO}_{3}^{-}: \mathrm{SO}_{4}^{2-}$ ratio in rain increased at the majority of sites due mostly to air pollution regulations of $\mathrm{SO}_{4}^{2-}$ precursors.
\end{abstract}

\section{Introduction}

The southwestern United States is experiencing rapid population growth, land-use change, drought, and variability in precipitation and water availability (Woodhouse et al., 2010; Cayan et al., 2010; Seager and Vecchi, 2010; Harpold et al., 2012), which both affect and are affected by the region's aerosol particles and precipitation. Ongoing changes in the Southwest's climate are reducing the relative contributions of winter snow versus summer rain to the annual water balance (Cayan et al., 2010) and shortening the duration of snow cover and melt (Harpold et al., 2012). Although chemical relationships between particulate matter and precipitation have been studied in a wide range of environments, few locations exhibit as wide a range of sensitivity to atmospheric chemistry as the Southwest. For example, dust deposition in seasonal snowpacks increases melt rate during spring in the mountains of Colorado (Painter et al., 2007). The amount of fine and coarse aerosol particles may also alter the amount and spatial distribution of potential rain or snow via their role as cloud condensation nuclei (CCN) and ice nuclei (IN), respectively (e.g Rosenfeld and Givati, 2006). In both desert and montane ecosystems, the deposition of nitrate and sulfate have been shown to be acidifying agents for aquatic ecosystems resources (e.g. Fenn et al., 2003), while excess nitrogen in precipitation has altered plant-soil nutrient relations and induced directional biological shifts in ecosystems (Fenn et al., 1998; Baron et al., 2000; Wolfe et al., 2003; Neff et al., 2008). Consequently, the composition and acidity of wet deposition in the Southwest have critical effects on terrestrial and aquatic ecosystems. 
Precipitation chemistry is governed largely by the composition of the seeds of warm cloud droplets (CCN) and snow (IN), and gases and particles that deposit to these hydrometeors. There have been limited attempts to examine precipitation chemistry in relation to air mass source origins and particulate matter composition in the Southwest. Hutchings et al. (2009) focused on monsoon clouds near Flagstaff, Arizona and suggested that windblown soils serve as $\mathrm{CCN}$ and can be found in cloud water. It is widely accepted that dust particles act as both CCN (Levin et al., 1996; Rosenfeld et al., 2001; Koehler et al., 2007) and IN (Isono and Ikebe, 1960; Kumai, 1961; Twohy and Gandrud, 1998; Heintzenberg et al., 1996; DeMott et al., 2003a, b; Sassen et al., 2003; Cziczo et al., 2004; Koehler et al., 2007; Prenni et al., 2009; Zimmermann et al., 2008), which is important for the Southwest as it has the highest dust concentrations in the United States (e.g. Malm et al., 2004). This is assisted by disrupted soils from agricultural activity, vehicles, construction, grazing, and mining operations (Schlesinger et al., 1990; Neff et al., 2005; Fernandez et al., 2008; Csavina et al., 2012). Atmospheric dust not only originates from regional sources in the Southwest and Mexico, but it can also be transported from distant regions such as Asia, especially in spring months (VanCuren and Cahill, 2002; Jaffe et al., 2003; Wells et al., 2007; Kavouras et al., 2009). In addition to dust, the region is impacted by diverse anthropogenic and biogenic sources with the relative strength of each of these sources being sensitive to meteorological and seasonal factors.

The goal of this work is to examine co-located aerosol and wet deposition chemical measurements at six Southwest sites with an aim to characterize their spatiotemporal trends and interrelationships. The analysis specifically aims to address the following questions: (i) What is the annual profile of rain/snow water accumulation, precipitation $\mathrm{pH}$, and composition of precipitation and aerosol particles?; (ii) What species are best correlated with each other in rain and snow?; (iii) What species are most influential towards rain and snow water pH?; (iv) How well-correlated are common species measured in aerosol and precipitation samples?; (v) What is the nature of the nitrate:sulfate ratio in precipitation and aerosol particles? and (vi) How have aerosol and precipitation species concentrations changed between 1995 and 2010?

\section{Data}

\subsection{Aerosol data}

Aerosol composition data were obtained from the Interagency Monitoring of Protected Visual Environments (IMPROVE) network (Malm et al., 1994, 2004; http://views. cira.colostate.edu/web/). IMPROVE aerosol monitoring stations are located primarily in National Parks and Wilderness Areas and contain samplers that collect ambient aerosol on filters over a period of $24 \mathrm{~h}$, typically every third day.
Prior to 2000, sampling was conducted twice each week with a $24 \mathrm{~h}$ duration per sample. The change in sampling frequency in 2000 is not expected to bias the results over the monthly and seasonal time scales of interest in this study. Collected samples are analyzed for ions, metals, and both organic carbon (OC) and elemental carbon (EC). Ammonium is not routinely measured in the IMPROVE program and thus its concentrations in precipitation are only discussed. Sampling protocols and additional details are provided elsewhere (http://vista.cira.colostate.edu/improve/Publications/ SOPs/UCDavis_SOPs/IMPROVE_SOPs.htm). Nitrate is vulnerable to measurement artifacts and this issue is minimized via the use of an annular denuder (to remove nitric acid, $\mathrm{HNO}_{3}$ ) and nylon filters as compared to Teflon to prevent $\mathrm{NO}_{3}^{-}$loss via recapture of volatilized $\mathrm{HNO}_{3}$ (Ames and Malm, 2001; Yu et al., 2005). This study uses data from six sites summarized in Table 1 and Fig. 1 in terms of location, altitude, and range of dates for which data are examined. Specific species concentrations discussed in this study are from the "fine" fraction of aerosol, $\mathrm{PM}_{2.5}$, while total mass concentrations are also reported for the "coarse" fraction, defined as $\mathrm{PM}_{10}-\mathrm{PM}_{2.5}$. Among the elemental measurements, $\mathrm{x}$-ray fluorescence (XRF) is used for iron $(\mathrm{Fe})$ and heavier elements while particle-induced $\mathrm{x}$-ray emission (PIXE) is used for elements ranging from sodium $(\mathrm{Na})$ to manganese $(\mathrm{Mn})$. Fine soil is discussed in this work and is calculated from IMPROVE tracer concentrations using the following equation (Malm et al., 2004):

Fine Soil $\left(\mu \mathrm{g} \mathrm{m}^{-3}\right)=2.2[\mathrm{Al}]+2.49[\mathrm{Si}]+1.63[\mathrm{Ca}]$

$$
+2.42[\mathrm{Fe}]+1.94[\mathrm{Ti}]
$$

Statistical methods used to analyze IMPROVE and the precipitation data below are briefly summarized in the Supplement.

\subsection{Precipitation data}

Precipitation chemistry and $\mathrm{pH}$ data are reported from six sites (Table 1 and Fig. 1) from the National Atmospheric Deposition Program (NADP) National Trends Network (NTN) (http://nadp.sws.uiuc.edu/data/ntndata.aspx) that span a gradient of summer rain being dominant to roughly equal contributions of summer rain and winter snow. These six stations are co-located with the IMPROVE stations. Each of the sites has a wet deposition collector that is only open during precipitation events. Weekly samples are obtained in cleaned containers, the contents of which are sent to the Central Analytical Laboratory (CAL) at the Illinois State Water Survey (ISWS) where the following measurements are conducted: free acidity (i.e. $\mathrm{pH}$ ), conductance, and concentrations of ammonium $\left(\mathrm{NH}_{4}^{+}\right)$, calcium $\left(\mathrm{Ca}^{2+}\right)$, chloride $\left(\mathrm{Cl}^{-}\right)$, magnesium $\left(\mathrm{Mg}^{2+}\right)$, nitrate $\left(\mathrm{NO}_{3}^{-}\right)$, potassium $\left(\mathrm{K}^{+}\right)$, sodium $\left(\mathrm{Na}^{+}\right)$, and sulfate $\left(\mathrm{SO}_{4}^{2-}\right)$. Data that were obtained from the NADP data repository have undergone quality control and assurance protocols 
Table 1. Summary of co-located aerosol (IMPROVE) and precipitation (NADP/NTN) data used with coordinates, altitudes, and range of full years in which data are analyzed. The location of sites is shown in Fig. 1. "NP" and "NM" refer to National Park and National Monument, respectively. Altitudes are ASL.

\begin{tabular}{lccccc}
\hline Station & State & Lat $\left({ }^{\circ}\right)$ & Lon $\left({ }^{\circ}\right)$ & Alt $(\mathrm{m})$ & Data analysis range \\
\hline Mesa Verde NP (NTN) & CO & 37.198 & -108.491 & 2162 & \multirow{2}{*}{ 1995-2010 } \\
Mesa Verde NP (IMPROVE) & CO & 37.198 & -108.491 & 2172 & \\
Chiricahua (NTN) & AZ & 32.010 & -109.389 & 1570 & \multirow{2}{*}{ 2000-2010 } \\
Chiricahua NM (IMPROVE) & AZ & 32.009 & -109.389 & 1555 & \\
Organ Pipe Cactus NM (NTN) & AZ & 31.949 & -112.802 & 501 & \multirow{2}{*}{ 2003-2010 } \\
Organ Pipe (IMPROVE) & AZ & 31.951 & -112.802 & 504 & \\
Bryce Canyon NP (NTN) & UT & 37.619 & -112.173 & 2477 & \multirow{2}{*}{ 1995-2010 } \\
Bryce Canyon NP (IMPROVE) & UT & 37.618 & -112.174 & 2481 & \\
Gila Cliff Dwellings NM (NTN) & NM & 33.220 & -108.235 & 1772 & \multirow{2}{*}{ 1995-2010 } \\
Gila Wilderness (IMPROVE) & NM & 33.220 & -108.235 & 1776 & \\
Bandelier NM (NTN) & NM & 35.779 & -106.266 & 1997 & 1995-2010 \\
Bandelier NM (IMPROVE) & NM & 35.780 & -106.266 & 1988 & \\
\hline
\end{tabular}

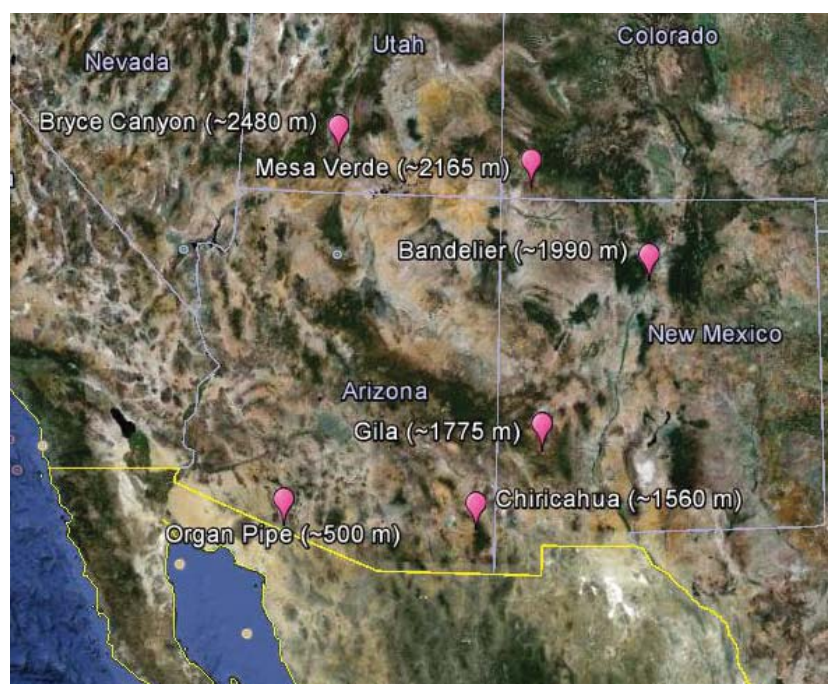

Fig. 1. Spatial map of co-located EPA IMPROVE and NADP/NTN stations used in this study.

(http://nadp.sws.uiuc.edu/data/ntndata.aspx). Data have been categorized to separate rain and snow, with no instances of rain-snow mixtures included in the analysis. Since sample handling procedures at all NADP/NTN sites changed substantially on 11 January 1994, data are only used beginning in 1 January 1995 or the first day of January in another year if data collection began in the middle of a year.

\subsection{Remote sensing data}

Regional maps of ultraviolet aerosol index (UV AI) were developed using data from the Ozone Monitoring Instrument (OMI) for the period between 2005-2008. Data were obtained at a resolution $1^{\circ} \times 1.25^{\circ}$ using a minimum threshold value of 0.5 (Hsu et al., 1999). The UV AI parameter serves as a proxy for absorbing aerosol particles (Torres et al., 1998), which are predominantly comprised of smoke and dust. UV AI is used here as a proxy for dust owing to its greater abundance relative to smoke in the region over the time scales examined in this work.

\section{Site descriptions}

The six sites studied represent areas throughout the southwestern United States influenced by varying degrees of pollution and meteorological conditions (Fig. 1). Organ Pipe National Monument is the lowest altitude site $(\sim 500 \mathrm{~m}$ a.s.l. $)$ and the closest to marine-derived emissions from the Pacific Ocean. Organ Pipe is approximately $16 \mathrm{~km}$ north of the USMexico border in southern Arizona. Anthropogenic pollution sources include the towns of Sonoyta, Mexico (population $\sim 15000, \sim 10 \mathrm{~km}$ south; http://www.inegi.org.mx/default. aspx) and Ajo, Arizona (city population $\sim 3500, \sim 36 \mathrm{~km}$ north; US Census Bureau, 2010). Chiricahua National Monument ( $\sim 1560$ ma.s.l.) is located in the Chiricahua Mountains in southeastern Arizona, approximately $18 \mathrm{~km}$ west of the Arizona-New Mexico border. Willcox, Arizona (city population 3800; US Census Bureau, 2010) is located $55 \mathrm{~km}$ west of Chiricahua and contains the Willcox Playa and the Apache Power Station, which is a coal-fired power station. Sierra Vista, Arizona (city population 44000 ; US Census Bureau, 2010) is located $97 \mathrm{~km}$ to the southwest of Chiricahua. The largest source of major urban pollution is Tucson, Arizona (city population 520 000; US Census Bureau, 2010), which is $150 \mathrm{~km}$ to the west of Chiricahua. This site can also be influenced by copper smelter emissions from the Mexican towns of Cananea and Nacozari $(140 \mathrm{~km}$ and $180 \mathrm{~km}$ south of Chiricahua, respectively).

The Gila stations $(\sim 1775 \mathrm{~m}$ a.s.l. $)$ are in southwestern New Mexico. The nearest town is Silver City, New Mexico (city population $~ 10000$; US Census Bureau, 2010), which includes a number of large open-pit copper mining 
operations. Lordsburg, New Mexico (city population 2800; US Census Bureau, 2010) is $70 \mathrm{~km}$ to the southwest and is home to the Lordsburg Generating Station, a natural-gas fired power station. A major source of urban pollution is Las Cruces, New Mexico (city population 98000 ; US Census Bureau, 2010), which is $170 \mathrm{~km}$ to the southeast. The Bandelier National Monument stations ( 1990 m a.s.l.) are located in northern central New Mexico. Bandelier is situated near the major population centers of Santa Fe, New Mexico (city population $\sim 68000$; US Census Bureau, 2010) and Albuquerque (city population $\sim 633000$; US Census Bureau, 2010). Albuquerque is home to two natural gas-fired power stations. The Reeves Generating Station is $72 \mathrm{~km}$ to the southwest and the Delta-Person Generating Station is $88 \mathrm{~km}$ to the southwest.

Mesa Verde National Park ( 2165 ma.s.1.) is in southwestern Colorado. It is close to the Colorado cities of Cortez (city population 8500; US Census Bureau, 2010) and Durango (city population $\sim 17000$; US Census Bureau, 2010). Approximately $57 \mathrm{~km}$ to the southeast is the city of Farmington (city population 46000; US Census Bureau, 2010), which contains two large coal-fired powers stations. The San Juan Generating Station and the Four Corners Power Plant are $46 \mathrm{~km}$ and $53 \mathrm{~km}$ south of Mesa Verde, respectively. Bryce Canyon National Park is the highest altitude site $(\sim 2480$ m a.s.l.) and is in southern Utah. Cedar City (city population $\sim 29000$; US Census Bureau, 2010) is located $80 \mathrm{~km}$ to the west and St. George (city population $\sim 70000$; US Census Bureau, 2010) is located $127 \mathrm{~km}$ to the southwest. The Navajo Generating Station is located $104 \mathrm{~km}$ to the southeast in Arizona and is a large coal-fired power station.

\section{Results}

\subsection{Air mass source regions}

Figure 2 summarizes the representative air mass source regions for each site as a function of season using threeday back-trajectory data from the NOAA HYSPLIT Model (Draxler and Rolph, 2012). Four seasons are defined in this study as follows: December-February (DJF), March-June (MAMJ), July-September (JAS), October-November (ON). The MAMJ season is meant to include the months with strongest dust influence, while JAS represents the monsoon season. Air masses from the Pacific Ocean influence all sites, with the strongest influence on Organ Pipe due to its proximity to the ocean. The three southernmost sites (Organ Pipe, Chiricahua, Gila) tend to exhibit similar trajectory frequency patterns relative to the three sites that are farther north. The former three stations that are closest to the US-Mexico border are most influenced by crustal emissions from the Sonoran Desert, dry lake beds such as Laguna Salada (southwest of Yuma, Arizona), the Chihuahuan Desert and a network of playas and alluvial, lacustrine, and aeolian sediments near

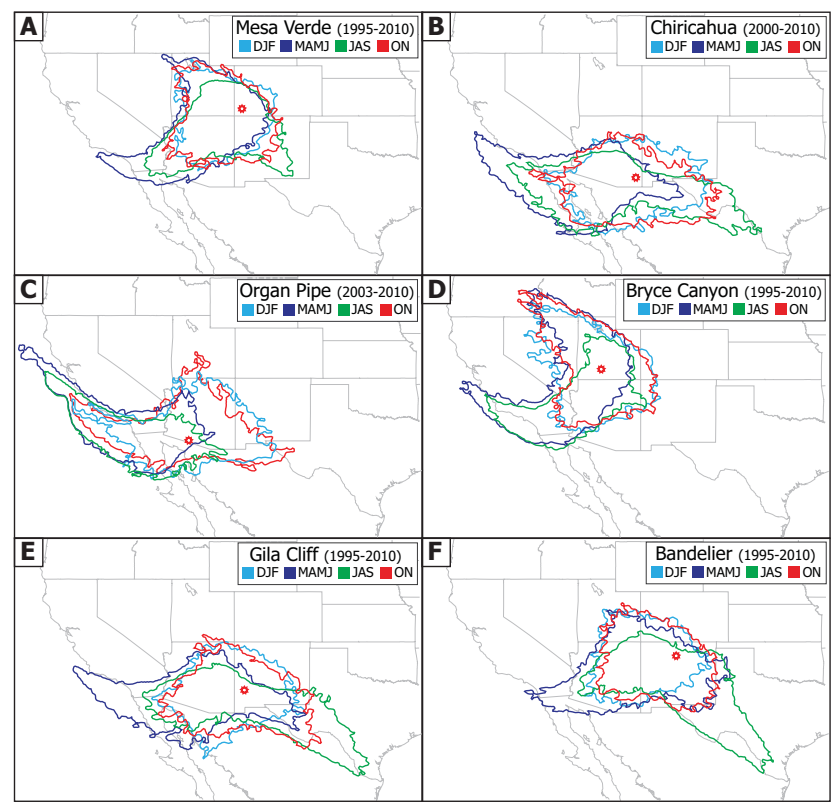

Fig. 2. Seasonal HYSPLIT data showing the approximate source regions for air parcels ending $10 \mathrm{~m}$ AGL at each of the six study sites that are represented by red open markers. The colored borders represent a minimum trajectory frequency of $1 \%$ using three-day back-trajectory data, where frequency is defined as the sum of the number of trajectories that passed through each point on the map divided by the number of trajectories analyzed.

the Mimbres Basin by southwestern New Mexico. The major seasonal difference at the easternmost sites is that the MAMJ trajectories originate farthest from the west, while JAS tends to coincide with more influence from towards the Gulf of Mexico. This is consistent with the arrival of monsoon moisture from the Gulf of Mexico during this time of year (Adams and Comrie, 1997; Higgins et al., 1997). Mesa Verde and Bryce Canyon exhibit similar trajectory frequency maps and receive more influence from the northwest direction as compared to the other sites. The DJF and ON seasons are characterized by being influenced by air with the smallest range of distance away from the study sites owing to meteorological conditions suppressing transport relative to the other two seasons. The majority of the backtrajectories include the Phoenix metropolitan area, which have previously been linked to enhanced levels of anthropogenic species (e.g. sulfate, lead, copper, cadmium) in cloud water more than $200 \mathrm{~km}$ to the north in Flagstaff, Arizona (Hutchings et al., 2009).

\subsection{Aerosol data}

The majority of the aerosol mass at the study sites resides in the coarse fraction, which is due to the strong influence of dust (Fig. 3). The two lowest altitude sites (Organ Pipe and Chiricahua) exhibit the highest coarse aerosol concentrations on an annual basis with their concentration peaks in 


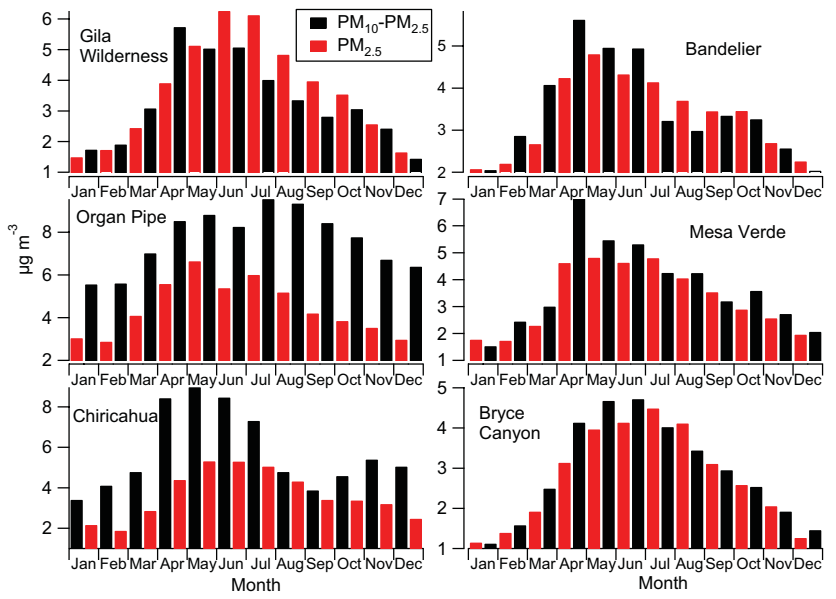

Fig. 3. Average monthly fine $\left(\mathrm{PM}_{2.5}\right)$ and coarse $\left(\mathrm{PM}_{10}-\mathrm{PM}_{2.5}\right)$ aerosol mass concentrations at six EPA IMPROVE sites. These results are based on data ranges shown in Table 1 for each site.

July $\left(9.55 \pm 7.41 \mu \mathrm{g} \mathrm{m}^{-3}\right)$ and May $\left(8.97 \pm 3.74 \mu \mathrm{g} \mathrm{m}^{-3}\right)$, respectively. Owing to Organ Pipe's lower altitude and closer proximity to dust and sea salt sources, it exhibits higher concentrations year-round with fairly sustained average coarse aerosol concentrations between April and September $\left(8.25-9.55 \mu \mathrm{g} \mathrm{m}^{-3}\right)$. The spatial and temporal patterns in coarse aerosol concentrations across the Southwest are consistent with seasonal UV AI maps (Fig. 4). The highest regional values occur during MAMJ, followed by JAS, ON, and then DJF. The sites co-located with the highest and lowest year-round UV AI levels are Organ Pipe and Bryce Canyon, respectively. A consistent feature at all sites except Organ Pipe is that the ratio of coarse: fine aerosol mass is highest during MAMJ (Fig. 5); this ratio can be used as a measure of when coarse dust aerosol influence is strongest from local sources (Tong et al., 2012). The average coarse : fine ratio at Organ Pipe is highest in DJF (1.98); the different behavior of this ratio at this site may be due to its proximity to marine-derived sea salt emissions (Fig. 2).

$\mathrm{PM}_{2.5}$ concentrations peak between May and July for the six sites, indicative of sources and production mechanisms (i.e. gas to particle conversion) that differ from coarse aerosol in the region. The most abundant contributors to $\mathrm{PM}_{2.5}$ are fine soil, organic carbon (OC), $\mathrm{SO}_{4}^{2-}$, and $\mathrm{NO}_{3}^{-}$(Fig. 6). Fine soil levels are highest in the spring months (April-May) owing largely to dry conditions, high wind speeds, and also the highest frequency of transported Asian dust (VanCuren and Cahill, 2002; Jaffe et al., 2003; Wells et al., 2007; Kavouras et al., 2009; Tong et al., 2012). The contributions of Ca, Mg, and $\mathrm{Na}$ to $\mathrm{PM}_{2.5}$ are highest during MAMJ due most likely to fine soil emissions (Fig. 5). Potassium is associated with crustal matter and biomass burning emissions, and its highest concentrations and mass fractions occur during MAMJ. Although no direct measurement of organic carbon (OC) is available in the precipitation datasets, $\mathrm{OC}$ in the $\mathrm{PM}_{2.5}$

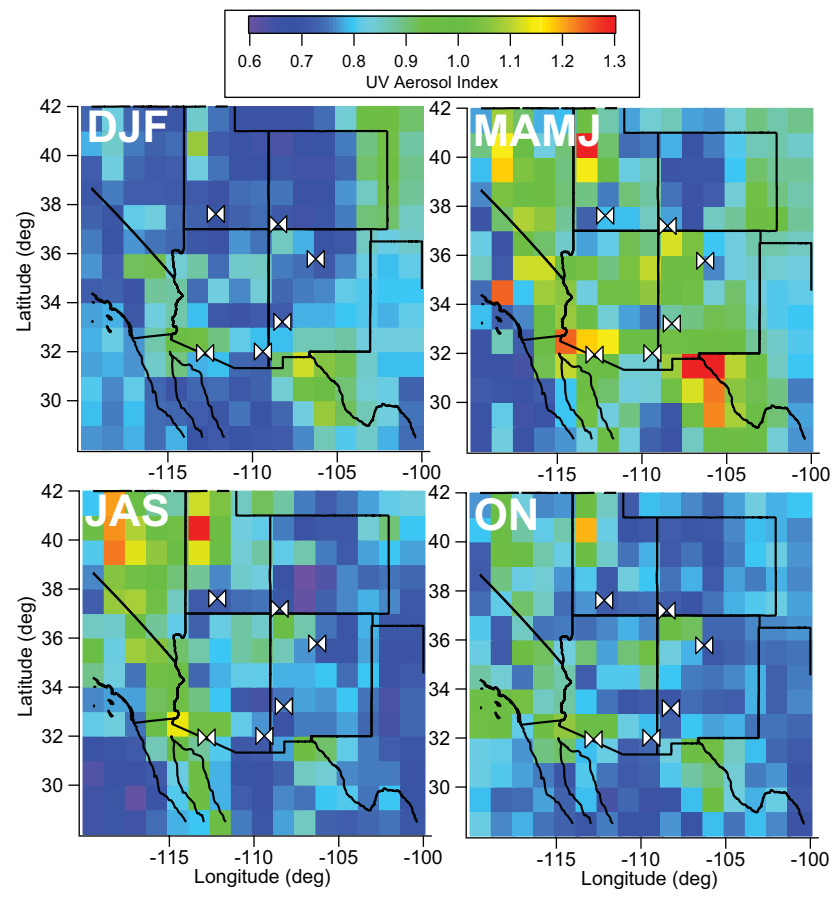

Fig. 4. Average remotely sensed ultraviolet aerosol index values (OMI) in the Southwest between 2005-2008 for four seasons. The white markers correspond to the six co-located pairs of IMPROVE and NADP/NTN stations.

fraction is still examined owing to its significant contribution ranging from 10-29\% depending on the site and season (Fig. 5); note that the inorganic aerosol constituents examined account for between $28-47 \%$ of $\mathrm{PM}_{2.5}$. Organic carbon has a variety of sources in the Southwest where it is produced via both direct emission and secondary production processes from sources including biomass burning, biological particles, biogenic emissions such as isoprene, combustion, meat cooking, plant debris, and dust (Bench et al., 2007; Schichtel et al., 2008; Holden et al., 2011; Sorooshian et al., 2011; Cahill et al., 2013; Youn et al., 2013). Although the atmospheric mixing height is largest between May-July in the region (Sorooshian et al., 2011), OC concentrations are the highest at all the sites during this time suggestive of the influence of biomass burning and secondary OC production. Sulfate production is enhanced during moist conditions, which occurs during the monsoon months in the Southwest. As a result, maximum concentrations (Fig. 6) and mass fractions (Fig. 5) for $\mathrm{SO}_{4}^{2-}$ are observed during JAS.

Nitrate is a marker for anthropogenic emissions as it often increases in concentration with decreasing mixing height in the winter months and because it is thermodynamically more stable in colder conditions; however, it is also associated with larger particles in the fine mode owing to reactions of $\mathrm{HNO}_{3}$ (or precursors) with dust and sea salt (Malm et al., 2003; Lee et al., 2004, 2008). As a result, $\mathrm{NO}_{3}^{-}$exhibits a bimodal concentration profile with a peak in the winter months 


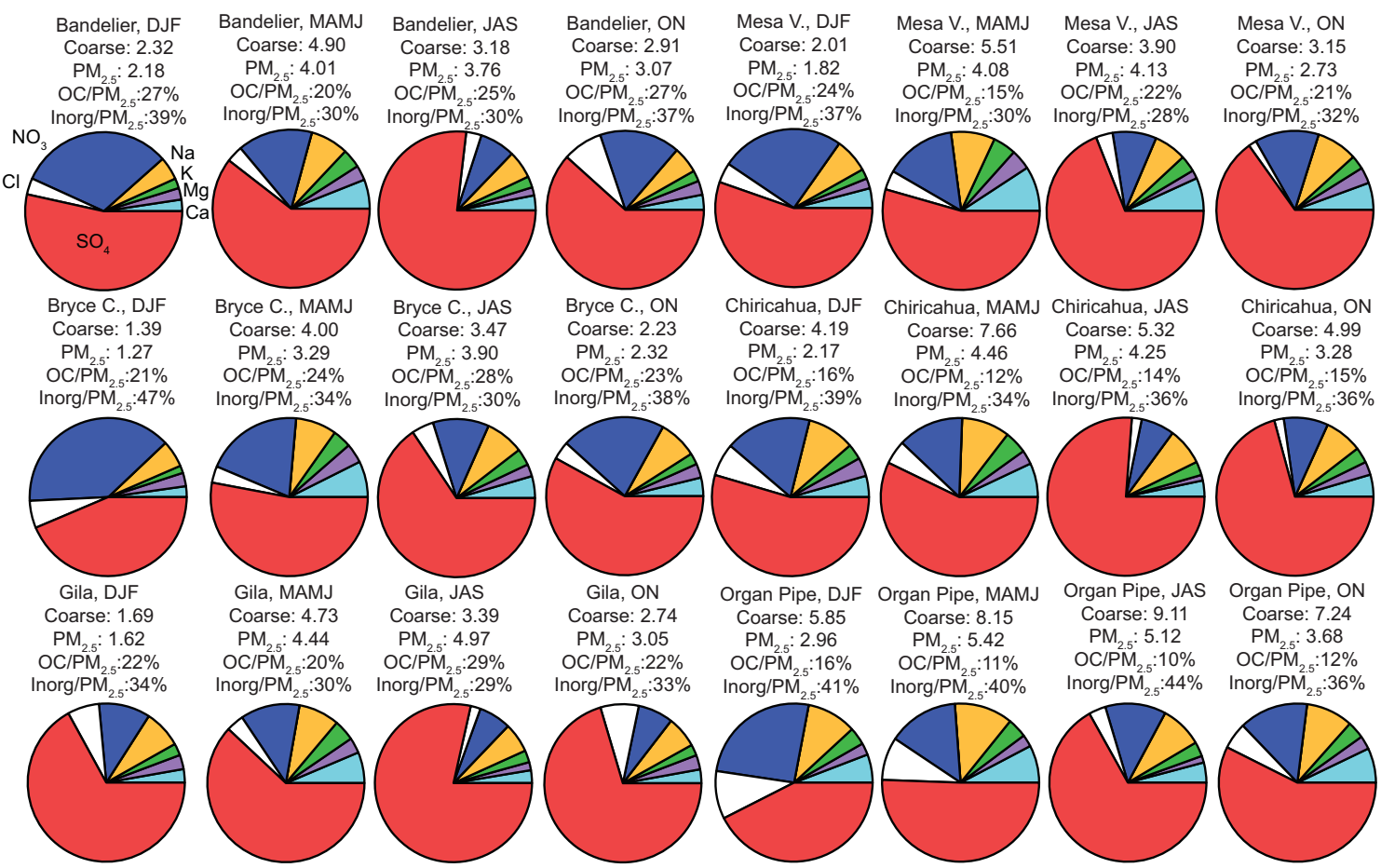

Fig. 5. Average monthly mass fractions of selected $\mathrm{PM}_{2.5}$ constituents for all six IMPROVE sites and for four seasons. The labels for each color in the top left pie are the same for the other pies. Also reported are average $\mathrm{PM}_{2.5}$ and coarse aerosol concentrations in units of $\mu \mathrm{g} \mathrm{m}^{-3}$, the concentration ratio of $\mathrm{OC}$ to $\mathrm{PM}_{2.5}$, and the concentration ratio of the sum of the seven inorganic components of the pies ('Inorg") relative to $\mathrm{PM}_{2.5}$. These results are based on data ranges in Table 1 for each site.

and during the spring months when soil dust is most abundant. Nitrate mass fractions are usually highest in DJF. Chloride exhibits peak concentrations in various months (March, May, June, October-December) depending on the site. Maximum concentrations observed at the majority of sites between March and June likely originate from a combination of crustal-derived particles and other sources such as biomass burning (e.g. Wonaschütz et al., 2011). Chloride is especially enhanced at Organ Pipe due to marine-derived sea salt, which is supported by higher mass fractions of $\mathrm{Cl}^{-}$and $\mathrm{Na}$ at this site relative to others (Fig. 5).

\subsection{Precipitation data}

\subsubsection{Annual rain and snow accumulation profiles}

Precipitation falls in two major modes (Fig. 7). The first is during DJF mostly as a result of Pacific Ocean frontal storms. These storms provide snow to high altitude sites and warm rain to lower altitude sites. The second mode is the summertime monsoon rainfall that typically occurs between July and October. The lowest altitude site, Organ Pipe, was the only one to have no snow data recorded. The next lowest altitude site, Chiricahua, has relatively similar amounts of snow and rain during the DJF period. This site also is characterized by major enhancements in precipitation during the monsoon season, with the two highest amounts in July and August (71 $\mathrm{mm}$ and $90 \mathrm{~mm}$, respectively). The relative amount of snow in DJF relative to rain during JAS increases as a function of altitude and distance to the north for the other sites: Bryce Canyon $>$ Mesa Verde $>$ Bandelier $>$ Gila Cliffs. Table S1 (Supplement) reports more specific statistics for precipitation data for each month and site. July and August are the months with the most frequent rain days ( $\sim 5-12$ depending on the site). The month with most frequent snow days ( 1-7 days, depending on the site) varied between December and February.

\subsubsection{Annual composition and $\mathrm{pH}$ profiles}

Rain $\mathrm{pH}$ levels are generally highest during MAMJ (Fig. 8) with annual averages at the sites ranging between 5 and 6 . Cloud water $\mathrm{pH}$ levels at a high-altitude site near Flagstaff, Arizona ranged between 5.12-6.66, and were said to be high due to crustal acid-neutralizing components (Hutchings et al., 2009). Studies in other regions have shown that carbonate bases associated with dust can neutralize acidic inputs to precipitation and increase $\mathrm{pH}$ (Schwikowski et al., 1995; Loye-Pilot and Morelli, 1988; Williams and Melack, 1991; Rhoades et al., 2010). Examples of regions with higher $\mathrm{pH}$ values $(>6)$ than those in the Southwest, mostly due to alkaline species (e.g. ammonium from agriculture and calcium 

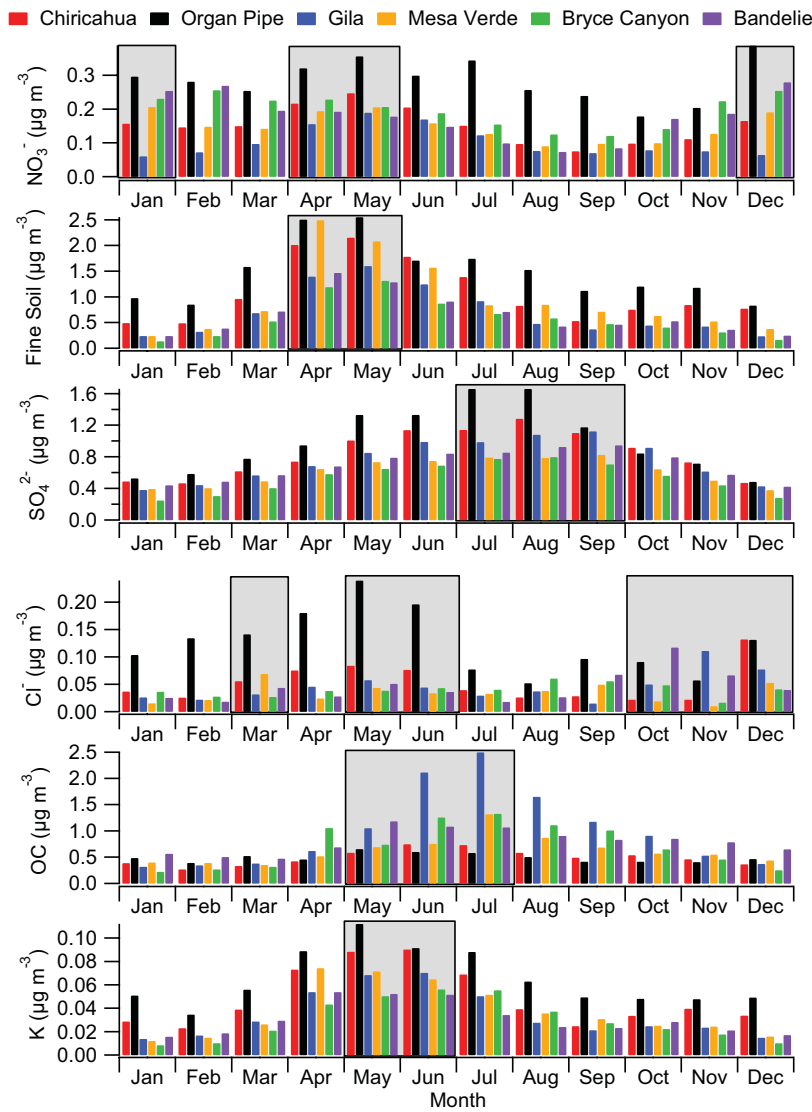

Fig. 6. Average monthly $\mathrm{PM}_{2.5}$ constituent mass concentrations at six EPA IMPROVE sites. Shaded regions represent when maxima are observed for individual or groups of sites. These results are based on data ranges shown in Table 1 for each site.

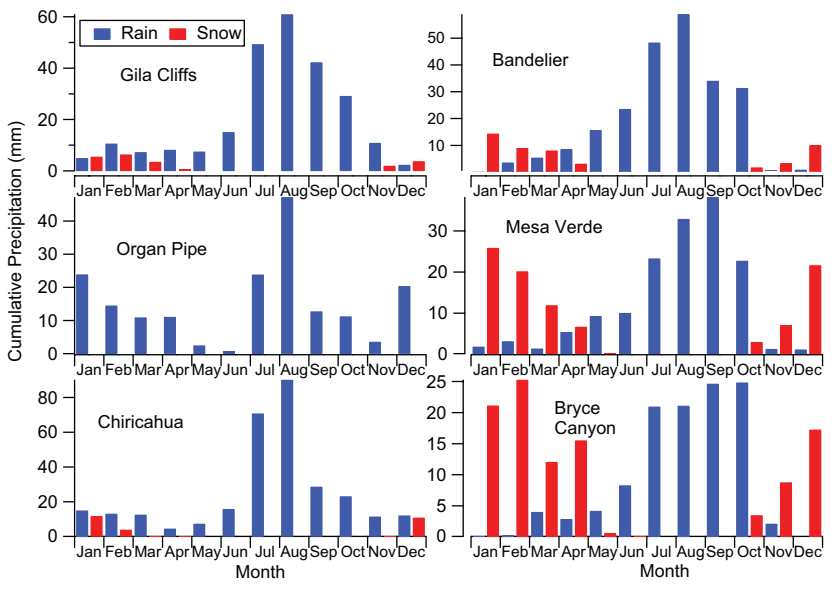

Fig. 7. Average monthly precipitation accumulation at the six NADP/NTN sites over the data ranges shown in Table 1.

carbonate from soil dust), are India (Khemani et al., 1987; Kulshrestha et al., 2005; Mouli et al., 2005), Jordan (AlKhashman, 2009), Niger (Galy-Lacaux et al., 2009), Spain (Avila et al., 1997, 1998), Israel (Herut et al., 2000), Phnom

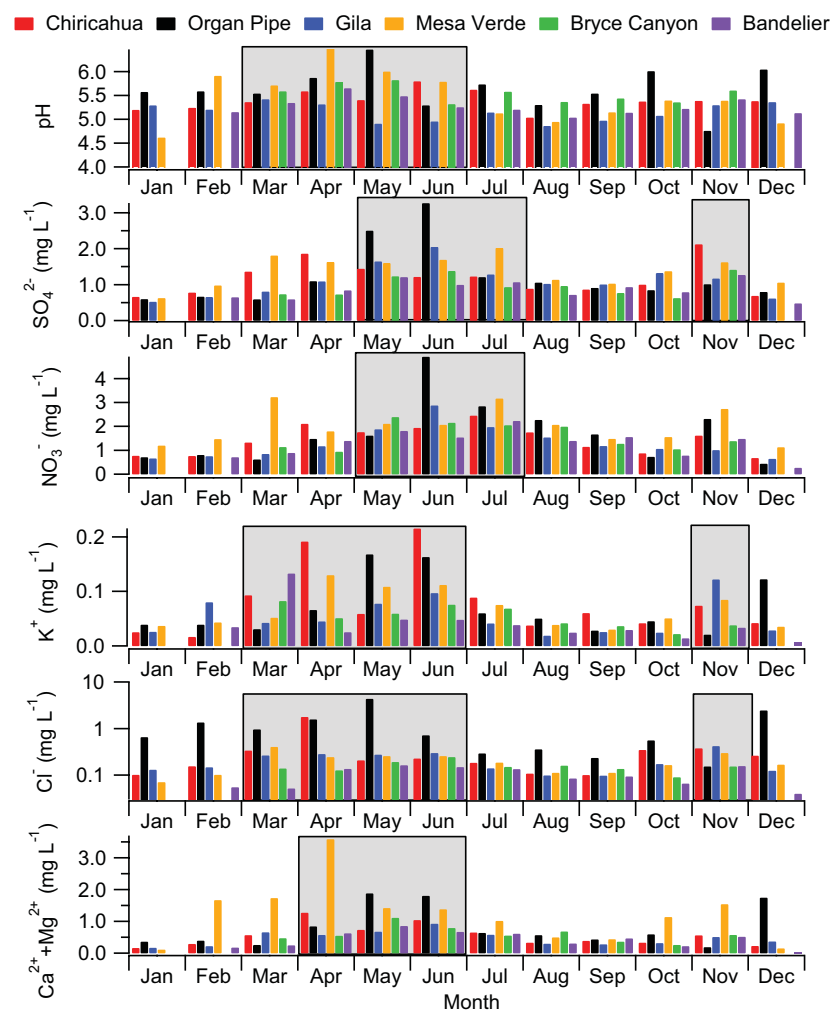

Fig. 8. Annual $\mathrm{pH}$ and concentration profiles for rain in the Southwest. Shaded regions represent when maxima are observed for individual or groups of sites. These results are based on data ranges shown in Table 1 for each site.

Penh (Cambodia), Ulaanbaatar (Mongolia) and Jiwozi and Shuzhan in China (EANET Executive Summary, 2011). Regions with lower rain $\mathrm{pH}$ values include the eastern United States, eastern Mediterranean, Canada, Turkey, Thailand, Singapore, and China (Granat et al., 1996; Al-Momani et al., 1997; Sirois et al., 2000; Balasubramanian et al., 2001; Qin and Huang, 2001; Basak and Alagha, 2004; Likens, 2007). It is cautioned that the temporal range of measurements is varied for these studies, which can affect $\mathrm{pH}$ comparisons; for example, reductions in sulfur dioxide $\left(\mathrm{SO}_{2}\right)$ emissions in the Southwest over the last several years have resulted in reduced particulate sulfate levels (Matichuk et al., 2006; Sorooshian et al., 2011), which influences precipitation $\mathrm{pH}$.

To more closely examine when dust impacts precipitation in the Southwest, $\mathrm{Ca}^{2+}$ and $\mathrm{Mg}^{2+}$ are used as rain tracer species (e.g. Stoorvogel et al., 1997; Reynolds et al., 2001; Rhoades et al., 2010); other crustal-derived rain constituents such as $\mathrm{K}^{+}$and $\mathrm{Na}^{+} / \mathrm{Cl}^{-}$are not used as they likely have contributions from biomass burning and sea salt, respectively. The rain water concentration sum of $\mathrm{Ca}^{2+}$ and $\mathrm{Mg}^{2+}$ is highest at all sites during the months of April-June (Fig. 8), which coincides with the highest levels of dust according to IMPROVE and satellite data (Figs. 3-6). Organ Pipe and Mesa Verde exhibit the highest levels of fine soil 


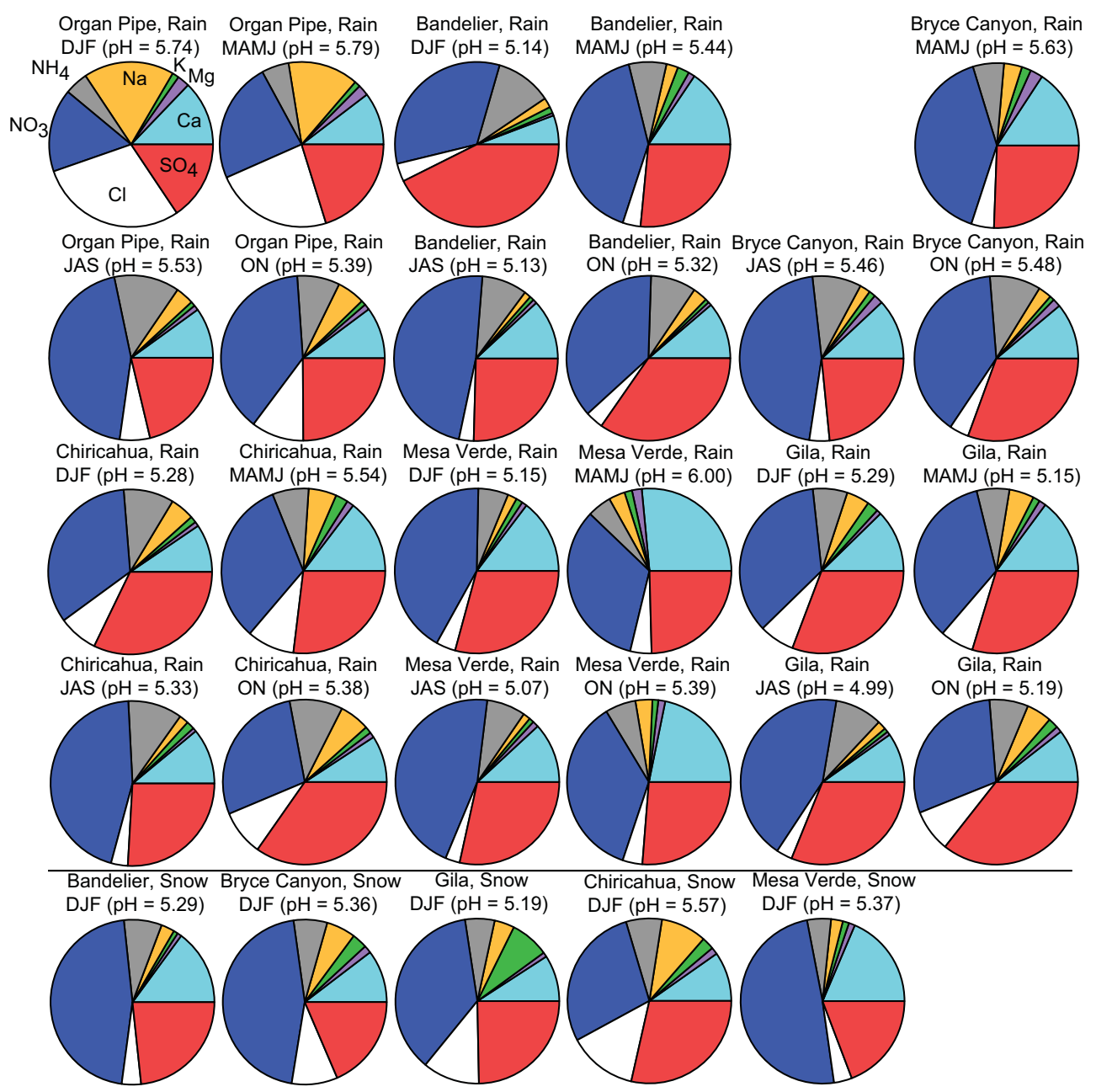

Fig. 9. (Top four rows) Summary of $\mathrm{pH}$ and chemical mass fraction data for rain during different periods of the year. (Bottom row) Snow $\mathrm{pH}$ and chemical mass fraction data for DJF, which is the season with the most snow data available. The labels in the top left pie are the same for the other pies. Note that during DJF there is no rain data for Bryce Canyon or snow data for Organ Pipe.

between April-May, which presumably explains why they also have the highest rain $\mathrm{pH}$ in those months. Rain $\mathrm{Cl}^{-}$and $\mathrm{K}^{+}$concentrations are also highest during MAMJ, likely due to crustal emissions (dust and sea salt); $\mathrm{Cl}^{-}$is most abundant at Organ Pipe for nearly the entire year due to sea salt from marine-derived air masses that impact the site year-round (Fig. 2). Nitrate and $\mathrm{SO}_{4}^{2-}$ exhibit different annual concentration profiles in precipitation as compared to $\mathrm{PM}_{2.5}$ for reasons that will be discussed subsequently.

Figure S1 (Supplement) shows annual cycles for snow water constituent concentrations. Annual snow $\mathrm{pH}$ values range between 5 and 6 at the various sites, similar to rain water. Snow $\mathrm{pH}$ and the concentration sum of $\mathrm{Ca}^{2+}$ and $\mathrm{Mg}^{2+}$ are highest between March and May for three sites (Gila Wilderness, Chiricahua, Mesa Verde), and between September and October for Bryce Canyon and Bandelier. The rest of the species exhibit their highest concentrations in a wide range of months depending on the site.

\subsubsection{Precipitation species mass fractions}

Either $\mathrm{Cl}^{-}, \mathrm{SO}_{4}^{2-}$, or $\mathrm{NO}_{3}^{-}$is the dominant rain anion on a mass basis depending on the site and season (Fig. 9). Chloride exhibits the highest anion mass fraction in Organ Pipe rain during DJF (29\%) due largely to sea salt. Nitrate is the dominant anion at Organ Pipe during JAS (44\%) and ON (39\%), while all three anions are nearly equivalent contributors during MAMJ (20-24\%). Sulfate and $\mathrm{NO}_{3}^{-}$exhibit the highest anion mass fractions in rain at the other sites with a consistent trend being that $\mathrm{NO}_{3}^{-}$accounts for the highest mass fraction in JAS and MAMJ. The highest cation mass fraction in rain was usually for $\mathrm{Ca}^{2+}(6-27 \%)$ at all six sites and seasons with the following exceptions: $\mathrm{NH}_{4}^{+}(10-13 \%$; Bandelier DJF, Chiricahua DJF/ON, Organ Pipe JAS); $\mathrm{Na}^{+}$ (14-18\%; Organ Pipe DJF/MAMJ). Snow mass fraction data are only shown for DJF in Fig. 9 due to insufficient data in other months. The highest snow cation mass fraction in 
DJF was always for $\mathrm{Ca}^{2+}(9-19 \%)$, followed by either $\mathrm{NH}_{4}^{+}$ $(5-7 \%), \mathrm{K}^{+}(8 \%)$, or $\mathrm{Na}^{+}(9 \%)$. The anion with the highest mass fraction in snow was usually $\mathrm{NO}_{3}^{-}(28-49 \%)$, followed by $\mathrm{SO}_{4}^{2-}(19-29 \%)$, and $\mathrm{Cl}^{-}(4-14 \%)$.

In other regions such as those associated with the Acid Deposition Monitoring Network in East Asia (EANET; EANET Executive Summary, 2011), the Tibetan Plateau, Canada, Spain, India, and Israel, the dominant precipitation cation has been reported to be either $\mathrm{Ca}^{2+}, \mathrm{Na}^{+}$, or $\mathrm{NH}_{4}^{+}$(Avila et al., 1998; Herut et al., 2000; Kulshrestha et al., 2005; Zhang et al., 2007 and references therein; Aherne et al., 2010; Yi et al., 2010; Zhang et al., 2012). Those studies also showed that $\mathrm{SO}_{4}^{2-}$ was the dominant anion, which may be due to significant anthropogenic influence in those studies; the one exception was in western Canada where marine-influenced air promoted $\mathrm{Cl}^{-}$to be the dominant anion. Calcium and $\mathrm{Cl}^{-}$were shown to be the dominant cation and anion, respectively, in Jordan rain water (Al-Khashman, 2009). Consistent with our results, Hutchings et al. (2009) showed that $\mathrm{NO}_{3}^{-}$was frequently more abundant than $\mathrm{SO}_{4}^{2-}$ in northern Arizona monsoon cloud water; however, they also showed that $\mathrm{NH}_{4}^{+}$was the dominant cation. San Joaquin Valley and Sacramento fog water in California exhibited high $\mathrm{NO}_{3}^{-}$: $\mathrm{SO}_{4}^{2-}$ concentration ratios (equivalent/equivalent) of 4.8 and 8.6 , respectively, due to the influence of agricultural emissions (Collett et al., 2002). It is cautioned again that such comparisons are sensitive to the time span of data examined due to reasons such as varying air quality regulations at different locations and times. Significant changes in the relative amounts of $\mathrm{SO}_{4}^{2-}$ and $\mathrm{NO}_{3}^{-}$have been observed in the United States since the 1980s (e.g. Butler and Likens, 1991; Lynch et al., 1995; Nilles and Conley, 2001; Butler et al., 2001; EPA, 2003).

\section{Discussion}

\subsection{Sources of precipitation species}

\subsubsection{Interrelationships between precipitation species concentrations}

Correlation matrices for rain and snow chemical concentrations are used to provide more support for common sources of species, using Organ Pipe and Bandelier as representative examples for rain and snow, respectively (Table 2). Tables S2-S3 report the rest of the matrices for the six sites, which show the same general relationships as those in Table 2. The crustal-derived species $\left(\mathrm{Ca}^{2+}, \mathrm{Mg}^{2+}, \mathrm{K}^{+}, \mathrm{Na}^{+}\right.$, $\mathrm{Cl}^{-}$) exhibit statistically significant correlations (95\% confidence using a two-tailed Student's $t$ test; this condition applies to all correlations reported hereinafter) with each other in both rain and snow ( $r=0.48-1.00, n=90-107)$, suggesting that their common source is dust or sea salt depending on the site. Sodium and $\mathrm{Cl}^{-}$are strongly correlated at the site closest to marine emissions, Organ Pipe $(r=1.00)$. These two species exhibit high correlations for both rain and snow at the other sites too $(r=0.66-0.97)$.

Sulfate, $\mathrm{NH}_{4}^{+}$, and $\mathrm{NO}_{3}^{-}$are highly correlated with each other relative to other species in rain and snow reflecting noncrustal sources, specifically anthropogenic emissions in the form of $\mathrm{SO}_{2}$, nitrogen oxides $\left(\mathrm{NO}_{\mathrm{x}}\right)$, and ammonia $\left(\mathrm{NH}_{3}\right)$. Sulfate, $\mathrm{NO}_{3}^{-}$, and $\mathrm{NH}_{4}^{+}$in precipitation originate from scavenging of these species in the aerosol phase and also from transfer of their vapor precursors: $\mathrm{SO}_{4}^{2-}$ from $\mathrm{SO}_{2} ; \mathrm{NO}_{3}^{-}$ from nitric acid $\left(\mathrm{HNO}_{3}\right)$, which originates from $\mathrm{NO}_{\mathrm{x}}$ emissions; $\mathrm{NH}_{4}^{+}$from $\mathrm{NH}_{3}$. Ammonium typically serves as a base for sulfuric and nitric acids and originates from $\mathrm{NH}_{3}$, which is emitted from livestock waste, fertilizer applications, biomass burning, motor vehicle emissions, and coal combustion (e.g. Apsimon et al., 1987; Asman and Janssen, 1987; Kleeman et al., 1999; Anderson et al., 2003; Battye et al., 2003; Sorooshian et al., 2008). The dominant route by which $\mathrm{SO}_{4}^{2-}$ becomes associated with drops is thought to be aerosol scavenging (e.g. van der Swaluw et al., 2011). Other work has shown that the close relationship between $\mathrm{SO}_{4}^{2-}$ and $\mathrm{NO}_{3}^{-}$in rain and snow is mainly linked to anthropogenic inputs (e.g. Wake et al., 1992; Legrand and Mayewski, 1997; Schwikowski et al., 1999; Preunkert et al., 2003; Olivier et al., 2006; Dias et al., 2012). Ammonia from anthropogenic sources has also been linked to soluble ion measurements in ice and rain (Kang et al., 2002; Hou et al., 2003).

The crustal cation species $\left(\mathrm{Ca}^{2+}, \mathrm{Mg}^{2+}, \mathrm{K}^{+}, \mathrm{Na}^{+}\right)$exhibit statistically significant correlations with $\mathrm{SO}_{4}^{2-}, \mathrm{NO}_{3}^{-}$, and $\mathrm{Cl}^{-}$at all sites. This is suggestive of reactions of acids (e.g. nitric, sulfuric, hydrochloric acids) with crustal surfaces such as dust and sea salt (e.g. Matsuki et al., 2010). This link is supported by a large inventory of previous work: (i) measurements in Asia indicate that dust is a significant source of $\mathrm{SO}_{4}^{2-}$, largely of anthropogenic origin which comes together with dust, in snow and glaciers (Wake et al., 1990; Kreutz et al., 2001; Zhao et al., 2011); (ii) a close association of $\mathrm{SO}_{4}^{2-}$ with crustal matter was argued to explain the close relationship between $\mathrm{SO}_{4}^{2-}$ and $\mathrm{Ca}^{2+}$ in rain water in India (Satyanarayana et al., 2010); (iii) Zhang et al. (2007) suggested that acids such as $\mathrm{HCl}$ react with windblown crustal particles to yield a high $\mathrm{Mg}^{2+} / \mathrm{Cl}^{-}$correlation in China; and (iv) dust surfaces have been shown to become coated with soluble species such as $\mathrm{SO}_{4}^{2-}, \mathrm{NO}_{3}^{-}$, and $\mathrm{Cl}^{-}$(Desbouefs et al., 2001; Sullivan et al., 2007; Matsuki et al., 2010) leading to enhanced hygroscopic properties (Levin et al., 1996; Koehler et al., 2007; Crumeyrolle et al., 2008; Sorooshian et al., 2012). Correlations between similar subsets of species (crustal species, $\mathrm{SO}_{4}^{2-} / \mathrm{NH}_{4}^{+} / \mathrm{NO}_{3}^{-}$, and the combination of the latter two) have also been observed in other regions such as the Mediterranean, Turkey, India, Brazil, Mexico, and China (Al-Momani et al., 1997; Basak and Agha, 2004; Safai et al., 2004; Mouli et al., 2005; Baez et al., 2007; 
Table 2. Correlation matrix ( $r$ values) for rain water constituent concentrations measured at Organ Pipe between 2003 and 2010 and snow water constituent concentrations measured at Bandelier between 1995 and 2010. Values are only shown when statistically significant (95\%) with a two-tailed Student's $t$ test. Refer to Supplement for all data for the six sites.

\begin{tabular}{|c|c|c|c|c|c|c|c|c|c|c|c|c|c|c|c|c|c|c|}
\hline & \multicolumn{9}{|c|}{ Organ Pipe Rain $(n=107)$} & \multicolumn{9}{|c|}{ Bandelier Snow $(n=90)$} \\
\hline & $\mathrm{Ca}$ & $\mathrm{Mg}$ & $\mathrm{K}$ & $\mathrm{Na}$ & $\mathrm{NH}_{4}$ & $\mathrm{NO}_{3}$ & $\mathrm{Cl}$ & $\mathrm{SO}_{4}$ & $\mathrm{pH}$ & $\mathrm{Ca}$ & $\mathrm{Mg}$ & $\mathrm{K}$ & $\mathrm{Na}$ & $\mathrm{NH}_{4}$ & $\mathrm{NO}_{3}$ & $\mathrm{Cl}$ & $\mathrm{SO}_{4}$ & $\mathrm{pH}$ \\
\hline $\mathrm{Ca}$ & 1.00 & & & & & & & & & 1.00 & & & & & & & & \\
\hline $\mathrm{Mg}$ & 0.76 & 1.00 & & & & & & & & 0.87 & 1.00 & & & & & & & \\
\hline K & 0.92 & 0.82 & 1.00 & & & & & & & 0.83 & 0.84 & 1.00 & & & & & & \\
\hline $\mathrm{Na}$ & 0.59 & 0.96 & 0.68 & 1.00 & & & & & & 0.68 & 0.76 & 0.70 & 1.00 & & & & & \\
\hline $\mathrm{NH}_{4}$ & 0.21 & - & 0.25 & - & 1.00 & & & & & - & 0.23 & 0.29 & 0.45 & 1.00 & & & & \\
\hline $\mathrm{NO}_{3}$ & 0.28 & - & 0.34 & - & 0.89 & 1.00 & & & & 0.28 & 0.36 & 0.41 & 0.43 & 0.61 & 1.00 & & & \\
\hline $\mathrm{Cl}$ & 0.59 & 0.96 & 0.68 & 1.00 & - & - & 1.00 & & & 0.48 & 0.61 & 0.53 & 0.85 & 0.44 & 0.38 & 1.00 & & \\
\hline $\mathrm{SO}_{4}$ & 0.47 & 0.45 & 0.56 & 0.28 & 0.67 & 0.79 & 0.26 & 1.00 & & 0.36 & 0.48 & 0.49 & 0.60 & 0.81 & 0.51 & 0.60 & 1.00 & \\
\hline $\mathrm{pH}$ & 0.44 & 0.54 & 0.49 & 0.50 & - & - & 0.51 & - & 1.00 & 0.72 & 0.72 & 0.65 & 0.43 & - & - & 0.21 & - & 1.00 \\
\hline
\end{tabular}

Table 3. Correlation $(r)$ of aerosol mass concentrations (fine soil, sulfate) and the coarse : fine mass concentration ratio with precipitation species mass concentrations. Values are only shown when statistically significant (95\%) with a two-tailed Student's $t$ test. There are no snow data at Organ Pipe. The sample range for data below is 39-240.

\begin{tabular}{|c|c|c|c|c|c|c|c|c|c|c|c|c|c|c|c|c|c|c|}
\hline & \multicolumn{6}{|c|}{ Particulate Fine Soil } & \multicolumn{6}{|c|}{ Particulate Sulfate } & \multicolumn{6}{|c|}{ Coarse:Fine Mass Ratio } \\
\hline & Band & $\mathrm{BC}$ & Chi & Gila & MV & $\mathrm{OP}$ & Band & $\mathrm{BC}$ & Chi & Gila & MV & OP & Band & $\mathrm{BC}$ & Chi & Gila & MV & $\mathrm{OP}$ \\
\hline Rain $\mathrm{Ca}$ & 0.27 & 0.40 & 0.33 & 0.32 & 0.15 & - & - & 0.23 & - & - & - & - & - & - & - & - & 0.18 & - \\
\hline Rain Mg & 0.39 & 0.45 & 0.25 & 0.34 & 0.20 & - & - & 0.22 & - & - & - & - & - & - & - & 0.12 & - & - \\
\hline Rain K & - & 0.23 & 0.23 & 0.15 & 0.31 & - & - & - & - & - & - & - & - & - & - & - & 0.16 & - \\
\hline Rain $\mathrm{Na}$ & 0.33 & 0.36 & - & 0.18 & 0.20 & - & - & 0.29 & - & - & - & - & - & - & - & - & - & - \\
\hline Rain $\mathrm{NH}_{4}$ & - & 0.22 & 0.26 & 0.16 & - & 0.23 & - & 0.18 & 0.19 & 0.21 & - & 0.30 & -0.16 & - & - & -0.13 & - & - \\
\hline Rain $\mathrm{NO}_{3}$ & - & 0.30 & 0.31 & 0.21 & - & 0.25 & - & 0.30 & 0.23 & 0.26 & - & 0.32 & -0.17 & - & - & - & - & - \\
\hline Rain $\mathrm{Cl}$ & 0.32 & 0.37 & - & 0.20 & 0.22 & - & - & 0.34 & - & - & - & - & - & - & - & 0.14 & - & - \\
\hline Rain $\mathrm{SO}_{4}$ & - & 0.28 & 0.23 & 0.19 & - & 0.24 & 0.14 & 0.41 & - & 0.39 & 0.20 & 0.29 & - & - & - & - & - & - \\
\hline Snow Ca & - & 0.23 & - & 0.73 & 0.74 & - & - & - & - & - & -0.21 & - & 0.22 & 0.19 & - & 0.63 & 0.27 & - \\
\hline Snow Mg & - & 0.26 & - & 0.73 & 0.56 & - & - & - & - & - & -0.24 & - & 0.30 & 0.19 & - & 0.65 & 0.28 & - \\
\hline Snow K & - & - & - & 0.70 & 0.39 & - & - & - & - & - & -0.19 & - & 0.30 & - & - & 0.72 & 0.28 & - \\
\hline Snow $\mathrm{Na}$ & - & - & - & 0.59 & - & - & - & - & - & - & - & - & 0.34 & 0.17 & - & 0.57 & 0.27 & - \\
\hline Snow $\mathrm{NH}_{4}$ & - & 0.18 & - & 0.38 & - & - & - & - & - & - & - & - & - & - & - & 0.36 & - & - \\
\hline Snow $\mathrm{NO}_{3}$ & - & - & - & 0.46 & - & - & - & 0.15 & - & - & - & - & 0.22 & - & - & 0.48 & - & - \\
\hline Snow $\mathrm{Cl}$ & - & - & - & 0.59 & - & - & - & - & - & - & - & - & - & - & - & 0.60 & 0.23 & - \\
\hline Snow $\mathrm{SO}_{4}$ & - & 0.24 & - & 0.61 & 0.34 & - & - & 0.18 & - & - & - & - & - & - & - & 0.57 & - & - \\
\hline
\end{tabular}

Zhang et al., 2007; Teixeira et al., 2008; Yi et al., 2010; Raman and Ramachandran, 2011).

\subsubsection{Interrelationships between aerosol and precipitation species}

It is of interest to examine the extent to which aerosol and precipitation species concentrations are related. $\mathrm{As} \mathrm{SO}_{4}^{2-}$ and fine soil represent the most abundant $\mathrm{PM}_{2.5}$ constituents of interest in this work (excluding other constituents such as carbonaceous species), their particulate concentrations are compared to all precipitation species concentrations in Table 3. The following factors could bias the interpretation of these results: (i) gases that partition to hydrometeors; and (ii) different air masses affecting altitudes at which the IMPROVE measurements take place and where precipitation is produced. With the exception of Organ Pipe, crustal-derived species in rain $\left(\mathrm{Ca}^{2+}, \mathrm{Mg}^{2+}, \mathrm{K}^{+}, \mathrm{Cl}^{-}, \mathrm{Na}^{+}\right)$exhibit statistically significant correlations with fine soil. Although not shown in Table 3, particulate $\mathrm{Cl}^{-}$was only correlated with rain $\mathrm{Cl}^{-}(r=0.29 ; n=105)$ at one site (Organ Pipe) because of the proximity of Organ Pipe to the Pacific Ocean; particulate $\mathrm{Cl}^{-}$was also correlated with $\mathrm{Na}^{+}$at this site $(r=0.29, n=105)$. Interestingly, $\mathrm{NH}_{4}^{+}, \mathrm{SO}_{4}^{2-}$, and $\mathrm{NO}_{3}^{-}$in rain are also correlated with fine soil at four sites including Organ Pipe. This result is consistent with these same anthropogenically-related species being related to the crustal species in the rain data. Fine soil levels exhibit statistically significant correlations with those of crustal-derived species in snow at Bryce Canyon, Mesa Verde, and Gila.

Particulate $\mathrm{SO}_{4}^{2-}$ exhibits a statistically significant correlation with $\mathrm{SO}_{4}^{2-}$ in rain at all sites except Chiricahua. Particulate $\mathrm{SO}_{4}^{2-}$ was also correlated with $\mathrm{NO}_{3}^{-}$and $\mathrm{NH}_{4}^{+}$in rain at four sites including Organ Pipe and Chiricahua. Particulate $\mathrm{SO}_{4}^{2-}$ exhibits few statistically significant correlations with snow species: it only exhibited positive correlations with $\mathrm{SO}_{4}^{2-}$ and $\mathrm{NO}_{3}^{-}$at Bryce Canyon. The different 
relationships of particulate $\mathrm{SO}_{4}^{2-}$ with $\mathrm{SO}_{4}^{2-}$ in rain and snow may be caused by the vertical structure of $\mathrm{SO}_{4}^{2-}$ (and precursors) in the atmosphere and the varying degree to which $\mathrm{SO}_{4}^{2-}$-enriched particles act as $\mathrm{CCN}$ versus IN in the region. Sulfate (and precursor) concentrations decrease with altitude since its sources are near the surface. It is noted that monthlyaveraged particulate $\mathrm{SO}_{4}^{2-}$ concentrations generally decrease from the lowest-elevation IMPROVE stations to the highest ones (Fig. 6). Sulfate-rich particles are hygroscopic and expected to be efficient CCN, which likely are removed by warm rain prior to reaching higher freezing altitudes where IN activation occurs.

Motivated by previous findings that dust particles act as IN, the coarse : fine aerosol mass concentration ratio is compared to snow and rain chemical concentrations (Table 3). The coarse : fine ratio exhibited statistically insignificant correlations with most rain water species at all sites. However, the same ratio is positively correlated with snow species at all sites except Chiricahua and Organ Pipe, where the latter site experienced no snow. The coarse : fine ratio was typically only correlated with the crustal species $\left(\mathrm{Ca}^{2+}, \mathrm{Mg}^{2+}\right.$, $\mathrm{Na}^{+}, \mathrm{K}^{+}, \mathrm{Cl}^{-}$) and $\mathrm{NO}_{3}^{-}$, suggestive of a preferential role of coarse particles as IN in the region.

\subsection{Species influencing precipitation $\mathrm{pH}$}

The six sites exhibit similar interrelationships between precipitation chemical concentrations and $\mathrm{pH}$ (Table 2 and Tables S2-S3). The crustal-derived rain and snow species $\left(\mathrm{Ca}^{2+}, \mathrm{Mg}^{2+}, \mathrm{Na}^{+}, \mathrm{K}^{+}\right)$are positively correlated with $\mathrm{pH}$. The $\mathrm{PM}_{2.5}$ aerosol constituents that rain and snow $\mathrm{pH}$ are best correlated with are $\mathrm{Ca}, \mathrm{K}, \mathrm{Na}$, and fine soil (Table S4). These results provide support for dust increasing precipitation $\mathrm{pH}$ in the region, which is consistent with increases in the following parameters during the season with highest rain $\mathrm{pH}$ (i.e. MAMJ): fine soil and coarse aerosol concentrations, particulate crustal species concentrations $(\mathrm{Ca}, \mathrm{Mg}$, $\mathrm{Na}$ ), the coarse : fine aerosol ratio, and UV AI. The MAMJ $\mathrm{pH}$ peak in the Southwest is in contrast to India, where the highest values are observed during the monsoon due to large inputs of sea salt from marine-derived air masses (Satyanarayana et al., 2010). Ammonium was also positively correlated with $\mathrm{pH}$ at three sites (Bryce Canyon, Bandelier, Chiricahua), albeit more weakly than other cations. The weaker relationship between $\mathrm{pH}$ and $\mathrm{NH}_{4}^{+}$as compared to traditional crustal-derived bases such as $\mathrm{Ca}^{2+}$ suggests that the latter are more effective regionally as neutralization agents; this has also been observed in other regions such as the Eastern Mediterranean and Turkey (e.g. Al-Momani et al., 1997; Basak and Alagha 2004). Sulfate is negatively correlated with snow (Bryce Canyon, Gila, Mesa Verde) and rain $\mathrm{pH}$ (Mesa Verde) because of its acidic nature. Sulfate is the main dominant source of acidity in precipitation in other regions such as Brazil (Teixiera et al., 2008).

\subsection{Nitrate:Sulfate ratio}

The precipitation $\mathrm{NO}_{3}^{-}: \mathrm{SO}_{4}^{2-}$ ratios in this study, and those of Hutchings et al. (2009) in the same region, are higher than those observed in other regions. In this study, the cumulative average at each site ranges from $0.97-1.49$ for rain and 0.74-2.08 for snow, using concentrations units of $\mu e q L^{-1}$. These units are now applied for comparison with documented values in the following regions: Brazil $(\sim 1.10$, Dias et al., 2012; 0.61, Migliavacca et al., 2004; $\sim 0.11$, Migliavacca et al., 2005); Turkey $(\sim 0.625$, Topcu et al., 2002); Jordan ( 0.51, Al-Khashman, 2005); India $(\sim 0.28$, Singh et al., 2007); Costa Rica ( 0.05, Herrera et al., 2009); Spain ( 0.46 from 1984-1993 and 0.94 from 1998-2009; Izquierdo et al., 2012); Mexico ( 1.03; Baez et al., 2007); and numerous sites in Asia including in China, Japan, the Philippines, Thailand, Vietnam, Malaysia, and Hong Kong ( $\sim 0.36-1.14$, Yeung et al., 2007). The sites with the lowest ratios were strongly influenced by $\mathrm{SO}_{2}$ and source types such as vehicles, volcanoes, refineries, petrochemical activity, and thermoelectric plants. The $\mathrm{NO}_{3}^{-}: \mathrm{SO}_{4}^{2-}$ ratio is hypothesized to be larger in the Southwest due to some combination of the following: (i) different time ranges of data collection, which would make the comparisons less meaningful due to varying levels of pollution regulations at different times and locations; (ii) reduced $\mathrm{SO}_{2}$ emissions as compared to the other regions; and (iii) enhanced $\mathrm{NO}_{3}^{-}$either due to its association with crustal matter or partitioning of its gaseous precursors into rain and snow. With regard to periods of data collection, it is critical to note that at least in North America, more significant reductions in $\mathrm{SO}_{2}$ as compared to $\mathrm{NO}_{\mathrm{x}}$ over recent decades likely bias intercomparisons of $\mathrm{NO}_{3}^{-}: \mathrm{SO}_{4}^{2-}$ ratios between different studies (e.g. EPA, 2003; Kvale and Pryor, 2006). Measurements in the eastern United States have pointed to reductions in precipitation sulfate unlike nitrate since the 1980s (e.g. Butler and Likens, 1991; Lynch et al., 1995; Nilles and Conley, 2001; Butler et al., 2001).

The precipitation $\mathrm{NO}_{3}^{-}: \mathrm{SO}_{4}^{2-}$ ratios in this study are also interesting in the following two ways: (i) they are higher in precipitation samples as compared to $\mathrm{PM}_{2.5}(0.16-0.47)$; and (ii) the $\mathrm{NO}_{3}^{-}: \mathrm{SO}_{4}^{2-}$ ratio in rain typically increases from DJF (0.64-1.16) until JAS (1.09-1.63) before decreasing again, which is the opposite temporal trend for the particulate $\mathrm{NO}_{3}^{-}: \mathrm{SO}_{4}^{2-}$ ratio. One explanation for both findings could be that the coarse aerosol fraction has higher $\mathrm{NO}_{3}^{-}: \mathrm{SO}_{4}^{2-}$ ratios than what is reported for $\mathrm{PM}_{2.5}$, and that those larger particles efficiently serve as $\mathrm{CCN}$ and IN thereby driving up the ratio in precipitation. To indirectly examine the potential role of coarse aerosol in influencing the precipitation ratios, the coarse : fine aerosol mass ratio was compared to the $\mathrm{NO}_{3}^{-}: \mathrm{SO}_{4}^{2-}$ rain water ratio (Fig. S2). The two ratios do not exhibit a statistically significant positive relationship, and the coarse: fine ratio is typically the smallest in JAS. This weakens the case for nucleation scavenging of coarse particles with high $\mathrm{NO}_{3}^{-}: \mathrm{SO}_{4}^{2-}$ ratios, assuming that the 
air masses affecting clouds are similar to those influencing the IMPROVE stations. Another potential explanation is that gaseous precursors of $\mathrm{NO}_{3}^{-}$are scavenged more effectively in clouds relative to those for $\mathrm{SO}_{4}^{2-}$. Hayden et al. (2008) used airborne measurements to show that the $\mathrm{NO}_{3}^{-}: \mathrm{SO}_{4}^{2-}$ ratio usually was higher in cloud drop residual particles than sub-cloud particles, and that the predominant mechanism by which $\mathrm{NO}_{3}^{-}$partitioned to drops was by transfer of gas-phase $\mathrm{HNO}_{3}$. That study showed that unlike $\mathrm{NO}_{3}^{-}, \mathrm{SO}_{4}^{2-}$ partitioned to drops mainly by nucleation scavenging. Independent measurements on a mountaintop in Sweden showed that $\mathrm{NO}_{3}^{-}$activated more efficiently than $\mathrm{SO}_{4}^{2-}$ into cloud drops (Drewnick et al., 2007). However, our results show that particulate $\mathrm{NO}_{3}^{-}$concentrations only exhibit a statistically significant correlation with precipitation $\mathrm{NO}_{3}^{-}$levels at one of the six sites (Gila: $r=0.34, n=265$ ), whereas $\mathrm{SO}_{4}^{2-}$ shows a positive relationship between rain and aerosol at five of the six sites. Therefore, the preferential activation of $\mathrm{NO}_{3}^{-}$rather than $\mathrm{SO}_{4}^{2-}$ is ruled out here as the explanation. A more plausible explanation could be the efficient transfer of gaseous precursors of $\mathrm{NO}_{3}^{-}$to rain and snow, which cannot be quantified with surface aerosol measurements. The annual cycle of $\mathrm{HNO}_{3}$ at a site in the Southwest (Johnson et al., 1994) was previously measured to be the same as $\mathrm{NO}_{3}^{-}: \mathrm{SO}_{4}^{2-}$ in our study, which can help explain the increase of this ratio in rain from the wintertime to JAS.

Another interesting observation in the Southwest is that the $\mathrm{NO}_{3}^{-}$mass fraction and the $\mathrm{NO}_{3}^{-}: \mathrm{SO}_{4}^{2-}$ ratio are both higher in snow relative to rain during DJF. In contrast, $\mathrm{NH}_{4}^{+}$ and $\mathrm{SO}_{4}^{2-}$ both exhibit higher overall mass fractions in rain relative to snow during DJF. One explanation is the efficient adsorption of gaseous $\mathrm{NO}_{3}^{-}$precursors such as $\mathrm{HNO}_{3}$ to snow (e.g. Jacobi et al., 2012); however, the relative strength of partitioning of $\mathrm{HNO}_{3}$ to rain drops and snow is uncertain and requires additional investigation for this region. Another explanation could be the preferential role of different particle types in serving as $\mathrm{CCN}$ versus IN, which was already suggested to explain why particulate $\mathrm{SO}_{4}^{2-}$ was mainly correlated with $\mathrm{SO}_{4}^{2-}$ in rain rather than snow. More effective nucleation scavenging of hygroscopic particles containing $\mathrm{SO}_{4}^{2-}$ at lower altitudes in the form of CCN would limit their ability to reach higher altitudes where deeper clouds produce snow. At those higher altitudes, dust particles can serve as effective IN (Isono and Ikebe, 1960; Kumai, 1961; Twohy and Gandrud, 1998; Heintzenberg et al., 1996; DeMott et al., 2003a, b; Sassen et al., 2003; Czizco et al., 2004; Koehler et al., 2007; Prenni et al., 2007; Zimmermann et al., 2008), and as noted already, they contain enhanced levels of $\mathrm{NO}_{3}^{-}$ due to reactions with $\mathrm{HNO}_{3}$ (e.g. Malm et al., 2004; Lee et al., 2008). This speculation is partly supported by the finding that the coarse: fine aerosol ratio was positively correlated with snow $\mathrm{pH}$ at more sites (Bryce Canyon, Gila, Mesa Verde) than with rain $\mathrm{pH}$ (Mesa Verde). But a conflicting re- sult is that the snow ratio of $\mathrm{NO}_{3}^{-}: \mathrm{SO}_{4}^{2-}$ does not exhibit a statistically significant relationship with the coarse: fine aerosol mass ratio at any site. It is unclear as to whether this is due to dissimilar air masses influencing altitudes where snow is produced relative to the IMPROVE stations. More detailed investigations would assist with explaining the findings above related to the $\mathrm{NO}_{3}^{-}: \mathrm{SO}_{4}^{2-}$ ratios, especially examining $\mathrm{HNO}_{3}$ partitioning behavior and the role of different particle types in serving as CCN and IN in the Southwest.

\subsection{Interannual variability in aerosol and precipitation chemistry}

Previous analyses of NADP/NTN concentration data over the United States between 1985 and 2002 showed general increases in ammonium, reductions in sulfate, and mixed changes in nitrate depending on location (Lehmann et al., 2005); furthermore, reductions in sulfate have been shown to be more significant as compared to nitrate (Lehmann and Gay, 2011). As JAS is the season with the most available precipitation data across all sites, a long-term trend analysis for this season shows that the only species in rain exhibiting a statistically significant concentration change is $\mathrm{SO}_{4}^{2-}$ (Table 4). This species exhibited a decreasing trend at Bryce Canyon $\left(-0.062 \mathrm{mg} \mathrm{L}^{-1} \mathrm{yr}^{-1}\right)$ and Gila Cliff $\left(-0.057 \mathrm{mg} \mathrm{L}^{-1} \mathrm{yr}^{-1}\right)$. The decreasing trend is ubiquitous across the region in the fine aerosol fraction, with the largest reduction at Organ Pipe $\left(-0.109 \mu \mathrm{g} \mathrm{m}^{-3} \mathrm{yr}^{-1}\right)$; the reduction at other sites ranged between -0.029 and $-0.047 \mu \mathrm{g} \mathrm{m}^{-3} \mathrm{yr}^{-1}$. This reduction in the region can be explained by air regulations of $\mathrm{SO}_{4}^{2-}$ precursors (e.g. Matichuk et al., 2006; Sorooshian et al., 2011). Nitrate does not exhibit a statistically significant change in concentration in rain or in particles, except relatively small reductions as compared to $\mathrm{SO}_{4}^{2-}$ at Chiricahua $\left(-0.006 \mu \mathrm{g} \mathrm{m}^{-3} \mathrm{yr}^{-1}\right)$ and Organ Pipe $\left(-0.016 \mu \mathrm{g} \mathrm{m}^{-3} \mathrm{yr}^{-1}\right)$. Other work in the Southwest has suggested that a lack of a change of $\mathrm{NO}_{3}^{-}$over the last decade in at least one part of the Southwest (i.e. southern Arizona) may be due to competing factors: (i) land-use changes (e.g. agricultural land to urban areas) can reduce $\mathrm{NH}_{3}$ emissions and particulate $\mathrm{NO}_{3}^{-}$formation; and (ii) higher $\mathrm{NO}_{\mathrm{x}}$ emissions linked to population growth and reductions in $\mathrm{SO}_{4}^{2-}$ allow for more $\mathrm{NH}_{3}$ to neutralize $\mathrm{HNO}_{3}$ to promote ammonium nitrate $\left(\mathrm{NH}_{4} \mathrm{NO}_{3}\right)$ production (Sorooshian et al., 2011). While the $\mathrm{NO}_{3}^{-}: \mathrm{SO}_{4}^{2-}$ ratio in the fine aerosol fraction only increased at one site (Mesa Verde), there was an increase in rain at all sites except Chiricahua and Organ Pipe. Rain pH has also increased at all sites except Mesa Verde and Organ Pipe; the increase at four of the sites is due to reductions in $\mathrm{SO}_{4}^{2-}$ as compared to increases in $\mathrm{NO}_{3}^{-}$. A potential reason as to why Organ Pipe does not show increases in either the $\mathrm{NO}_{3}^{-}: \mathrm{SO}_{4}^{2-}$ ratio or $\mathrm{pH}$, even though it showed the largest reduction in particulate $\mathrm{SO}_{4}^{2-}$, may be due to an increasingly important role for coarse particle types relative to fine particles. More 
Table 4. Long-term trend analysis for the Southwest monsoon season (JAS). Slopes of each parameter versus year are shown with correlation

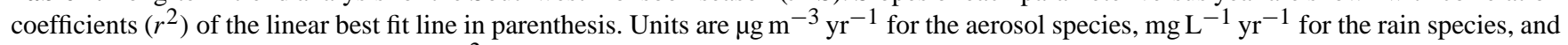
$\mathrm{yr}^{-1}$ for the coarse : fine ratio, $\mathrm{NO}_{3}^{-}: \mathrm{SO}_{4}^{2-}$ ratio, and $\mathrm{pH}$. No other common aerosol and rain water species are shown as they do not have statistically significant changes over the durations shown in Table 1.

\begin{tabular}{|c|c|c|c|c|c|c|}
\hline & Bandelier & Bryce Canyon & Chiricahua & Gila Cliff & Mesa Verde & Organ Pipe \\
\hline Particulate $\mathrm{SO}_{4}$ & $-0.037(0.56)$ & $-0.029(0.71)$ & $-0.038(0.52)$ & $-0.047(0.72)$ & $-0.042(0.78)$ & $-0.109(0.80)$ \\
\hline Particulate $\mathrm{NO}_{3}$ & & & $-0.006(0.43)$ & & & $-0.016(0.44)$ \\
\hline Particulate $\mathrm{NO}_{3}: \mathrm{SO}_{4}$ & & & & & $0.005(0.26)$ & \\
\hline Particulate Coarse: Fine & & & & & & $0.084(0.30)$ \\
\hline Rain $\mathrm{SO}_{4}$ & & $-0.062(0.28)$ & & $-0.057(0.53)$ & & \\
\hline Rain $\mathrm{NO}_{3}$ & & & & & & \\
\hline Rain $\mathrm{NO}_{3}: \mathrm{SO}_{4}$ & $0.037(0.33)$ & $0.049(0.26)$ & & $0.065(0.52)$ & $0.080(0.81)$ & \\
\hline Rain $\mathrm{pH}$ & $0.028(0.42)$ & $0.051(0.32)$ & $0.026(0.38)$ & $0.034(0.43)$ & & \\
\hline
\end{tabular}

specifically, Organ Pipe was the only site to show an increase in the coarse : fine aerosol mass ratio in JAS, with an increasing rate of $0.084 \mathrm{yr}^{-1}$. This result is suggestive of the presence of more coarse particle types, mainly sea salt and dust, that can react with $\mathrm{HNO}_{3}$ to form particulate $\mathrm{NO}_{3}^{-}$, simultaneous with reduced fine aerosol $\mathrm{SO}_{4}^{2-}$ over time.

\section{Conclusions}

This study characterized aerosol and precipitation composition at six sites in the US Southwest. The main results of this work are as follows, following the order of questions posed in Sect. 1:

i. Precipitation accumulation is concentrated in a wintertime mode (DJF) and a monsoon mode (JAS), with only warm rain associated with the latter. The relative amount of rain and snow during DJF depends on geography and altitude, with rain being more abundant farther south near the international border and at lower altitudes. All aerosol and precipitation species concentrations typically were highest during MAMJ (including precipitation $\mathrm{pH}$ ) due to increased dust concentrations.

ii. Statistically significant relationships in the regional rain and snow are observed for numerous crustal-derived species $\left(\mathrm{Ca}^{2+}, \mathrm{Mg}^{2+}, \mathrm{K}^{+}, \mathrm{Na}^{+}\right)$, mainly from dust, and a subset of species with anthropogenic sources $\left(\mathrm{NH}_{4}^{+}\right.$, $\mathrm{SO}_{4}^{2-}, \mathrm{NO}_{3}^{-}$). Species in the crustal group also exhibit positive relationships with $\mathrm{SO}_{4}^{2-}, \mathrm{NO}_{3}^{-}$, and $\mathrm{Cl}^{-}$, suggesting that acidic gases likely react with and partition to either coarse crustal particles or hydrometeors enriched with crustal constituents. Organ Pipe, the site closest to the Pacific Ocean, shows an especially strong relationship between $\mathrm{Na}^{+}$and $\mathrm{Cl}^{-}$in rain water due to sea salt influence, indicating that this aerosol type more strongly affects precipitation in parts of the Southwest closest to the ocean. iii. Rain and snow pH levels were usually between 5-6. Rain $\mathrm{pH}$ was highest during MAMJ, which was coincident with the highest rain and particulate concentrations of crustal-derived species $\left(\mathrm{Ca}^{2+}, \mathrm{Mg}^{2+}, \mathrm{K}^{+}, \mathrm{Na}^{+}\right)$. Rain and snow $\mathrm{pH}$ were generally well-correlated with these species showing that dust in the region is highly influential in acid-neutralization.

iv. Crustal-derived species in both rain and snow $\left(\mathrm{Ca}^{2+}\right.$, $\mathrm{Mg}^{2+}, \mathrm{K}^{+}, \mathrm{Cl}^{-}, \mathrm{Na}^{+}$) exhibit statistically significant correlations with particulate fine soil. The coarse: fine aerosol mass ratio was correlated with snow concentrations of crustal species $\left(\mathrm{Ca}^{2+}, \mathrm{Mg}^{2+}, \mathrm{Na}^{+}, \mathrm{K}^{+}, \mathrm{Cl}^{-}\right)$ and $\mathrm{NO}_{3}^{-}$, suggestive of a preferential role of coarse particles (mainly dust) as IN in the region. Particulate $\mathrm{SO}_{4}^{2-}$ concentrations exhibit a statistically significant correlation with rain $\mathrm{SO}_{4}^{2-}$ at most sites unlike snow, which may be related to a combination of the vertical structure of $\mathrm{SO}_{4}^{2-}$ (and precursors) in the atmosphere and the varying degree to which $\mathrm{SO}_{4}^{2-}$-enriched particles act as $\mathrm{CCN}$ versus IN in the region.

v. The precipitation $\mathrm{NO}_{3}^{-}: \mathrm{SO}_{4}^{2-}$ ratios in this study exhibit the following features: (i) higher in precipitation samples as compared to $\mathrm{PM}_{2.5}$; (ii) exhibit the opposite annual cycle compared to the particulate $\mathrm{NO}_{3}^{-}: \mathrm{SO}_{4}^{2-}$ ratio; and (iii) are higher in snow relative to rain during DJF. Multiple explanations are discussed that require more detailed investigation, including partitioning of gaseous $\mathrm{NO}_{3}^{-}$precursors (i.e. $\mathrm{HNO}_{3}$ ) to rain and snow.

vi. Long-term trend analysis for rain chemistry during the monsoon season (JAS) shows that the $\mathrm{NO}_{3}^{-}: \mathrm{SO}_{4}^{2-}$ ratio increased at most sites, due to air regulations reducing $\mathrm{SO}_{4}^{2-}$ precursor concentrations. Sulfate was the particulate species showing the most consistent reduction over time across the Southwest. The only site that did not exhibit an increase in either the $\mathrm{NO}_{3}^{-}: \mathrm{SO}_{4}^{2-}$ ratio or $\mathrm{pH}$ 
in rain was Organ Pipe, which exhibited the only longterm increase in the particulate coarse : fine mass ratio. Increasing relative amounts of coarse particles as compared to fine particles is thought to increase rain $\mathrm{pH}$ due to reduced influence from fine particulate $\mathrm{SO}_{4}^{2-}$ and increased influence from basic particulate species that are concentrated in the coarse fraction. Furthermore, reactions of $\mathrm{HNO}_{3}$ with coarse particle types and potential partitioning of this species to rain and snow can promote higher $\mathrm{NO}_{3}^{-}: \mathrm{SO}_{4}^{2-}$ ratios.

Future research is needed to test hypotheses used in this work to explain some of the results for the Southwest, including (i) the role of different particle types in serving as $\mathrm{CCN}$ and IN and (ii) the partitioning behavior of gases such as $\mathrm{HNO}_{3}$ to particles and hydrometeors. While this work has looked at factors influencing precipitation chemistry, it is noted that another major issue in the Southwest is deposition of aerosol particles to high altitude areas that reside in the snowpack or fall as summer rain and release nutrients into downstream ecosystems (Psenner, 1999; Lawrence and Neff, 2009). For example, mineral dust is thought to be among the strongest sources of atmospheric phosphorus (Okin et al., 2004; Mahowald et al., 2008) and its deposition at highelevation sites represents a major nutrient source for lakes (Morales-Baquero et al., 2006; Vicars and Sickman, 2011). Case studies in the Southwest have shown that dust events can influence the composition of snow water, specifically leading to enhancements in snowpack $\mathrm{pH}$ and calcium levels (Rhoades et al., 2010). Similar findings have linked dust to elemental composition of both precipitation and snow and changes in surface water chemistry (e.g. Landers et al., 1987; Turk et al., 2001). Other work has suggested that aerosol deposition can be a source of harmful contaminants such as lead (Liptzin and Seastedt, 2010).

Dust particles can also have a large impact on the melt rate of mountain snowpacks in Colorado by lowering the albedo, from 0.7 to 0.4 on average, and thereby increasing shortwave radiation inputs to the snowpack (Painter et al., 2010; Skiles et al., 2012). We observed the highest coarse aerosol mass concentrations and other proxies of dust during MAMJ when snow is on the ground at most of the mountains surrounding the study sites. Recent work from Colorado has shown that the advancement in the loss of snow cover from dust, due to faster melts, is linearly related to the amount of dust in the snowpack, despite variability in irradiance and the timing of dust deposition (Skiles et al., 2012). Predicting the amounts of wet and dry dust deposition to and from the Southwest is therefore critical to predicting snowmelt rates and downstream water resources of the Colorado River Basin (Painter et al., 2010). More research is necessary to combine information on dust sources and deposition, as done in the current study, with regional variability in hydroclimate and snow processes (Harpold et al., 2012) in the mountains of the western US.

\section{Supplementary material related to this article is available online at: http://www.atmos-chem-phys.net/13/ 7361/2013/acp-13-7361-2013-supplement.pdf.}

Acknowledgements. This research was supported by the Technology and Research Initiative Fund (TRIF), administered by the Arizona Board of Regents through the University of Arizona Water, Environmental, and Energy Solutions (WEES) initiative. Support was also provided by Grant 2 P42 ES04940-11 from the National Institute of Environmental Health Sciences (NIEHS) Superfund Research Program, NIH. The authors gratefully acknowledge the NOAA Air Resources Laboratory (ARL) for the provision of the HYSPLIT transport and dispersion model and READY website (http://ready.arl.noaa.gov) used in this publication. The authors also acknowledge IMPROVE, NADP, and the Illinois State Water Survey for providing data. Some of the analyses and visualizations used in this study were produced with the Giovanni online data system, developed and maintained by the NASA GES DISC.

Edited by: H. Tost

\section{References}

Adams, D. K. and Comrie, A. C.: The North American monsoon, B. Am. Meteorol. Soc., 78, 2197-2213, 1997.

Aherne, J., Mongeon, A., and Watmough, S. A.: Temporal and spatial trends in precipitation chemistry in the Georgia Basin, British Columbia, J. Limnol., 69, 4-10, doi:10.3274/J110-69-S102, 2010.

Al-Khashman, O. A.: Study of chemical composition in wet atmospheric precipitation in Eshidiya area, Jordan, Atmos. Environ., 39, 6175-6183, 2005.

Al-Khashman, O. A.: Chemical characteristics of rainwater collected at a western site of Jordan, Atmos. Res., 91, 53-61, 2009.

Al-Momani, I. F., Gullu, G., Olmez, I., Eler, U., Ortel, E., Sirin, G., and Tuncel, G.: Chemical composition of Eastern Mediterranean aerosol and precipitation: Indications of long-range transport, Pure Appl. Chem., 69, 41-46, 1997.

Ames, R. B. and Malm, W. C.: Comparison of sulfate and nitrate particle mass concentrations measured by IMPROVE and the CDN, Atmos. Environ., 35, 905-916, 2001.

Anderson, N., Strader, R., and Davidson, C.: Airborne reduced nitrogen: ammonia emissions from agriculture and other sources, Environ. Int., 29, 277-286, 2003.

Apsimon, H. M., Kruse, M., and Bell, J. N. B.: Ammonia emissions and their role in acid deposition, Atmos. Environ., 21, 19391946, 1987.

Asman, W. A. H. and Janssen, A. J.: A long-range transport model for ammonia and ammonium for Europe, Atmos. Environ., 21, 2099-2119, 1987.

Avila, A., Queralt-Mitjans, I., and Alarcón, M.: Minerological composition of Africa dust delivered by red rains over northeastern Spain, J. Geophys. Res., 102, 21977-21996, 1997.

Avila, A., Alarcón, M., and Queralt-Mitjans, I.: The chemical composition of dust transported in red rains-Its contribution to the 
biogeochemical cycle of a holm oak forest in Catalonia (Spain), Atmos. Environ., 32, 179-191, 1998.

Baez, A., Belmont, R., Garcia, R., Padilla, H., and Torres, M. C.: Chemical composition of rainwater collected at a southwest site of Mexico City, Mexico, Atmos. Res., 86, 61-75, 2007.

Balasubramanian, R., Victor, T., and Chun, N.: Chemical and statistical analysis of precipitation in Singapore, Water Air Soil Poll., 130, 451-456, 2001.

Baron, J. S., Rueth, H. M., Wolfe, A. M., Nydick, K. R., Allstott, E. J., Minear, J. T., and Moraska, B.: Ecosystem responses to nitrogen deposition in the Colorado Front Range, Ecosystems, 3, 352-368, 2000.

Basak, B. and Alagha, O.: The chemical composition of rainwater over Buyukcekmece Lake, Istanbul, Atmos. Res., 71, 275-288, 2004.

Battye, W., Aneja, V. P., and Roelle, P. A.: Evaluation and improvement of ammonia emissions inventories, Atmos. Environ., 37, 3873-3883, 2003.

Bench, G., Fallon, S., Schichtel, B., Malm, W., and McDade, C.: Relative contributions of fossil and contemporary carbon sources to $\mathrm{PM}_{2.5}$ aerosols at nine Interagency Monitoring for Protection of Visual Environments (IMPROVE) network sites, J. Geophys. Res., 112, D10205, doi:10.1029/2006jd007708, 2007.

Butler, T. J. and Likens, G. E.: The impact of changing regional emissions on precipitation chemistry in the eastern United-States, Atmos. Environ., 25, 305-315, doi:10.1016/09601686(91)90302-N, 1991.

Butler, T. J., Likens, G. E., and Stunder, B. J. B.: Regional-scale impacts of Phase I of the Clean Air Act Amendments in the USA: the relation between emissions and concentrations, both wet and dry, Atmos. Environ., 35, 1015-1028, doi:10.1016/S13522310(00)00386-1, 2001.

Cahill, T. M.: Annual cycle of size-resolved organic aerosol characterization in an urbanized desert environment, Atmos. Environ., 71, 226-233, doi:10.1016/j.atmosenv.2013.02.004, 2013.

Cayan, D. R., Das, T., Pierce, D. W., Barnett, T. P., Tyree, M., and Gershunov, A.: Future dryness in the southwest US and the hydrology of the early 21 st century drought, P. Natl. Acad. Sci. USA, 107, 21271-21276, doi:10.1073/pnas.0912391107, 2010.

Collett, J. L., Bator, A., Sherman, D. E., Moore, K. F., Hoag, K. J., Demoz, B. B., Rao, X., and Reilly, J. E.: The chemical composition of fogs and intercepted clouds in the United States, Atmos. Res., 64, 29-40, doi:10.1016/S0169-8095(02)00077-7, 2002.

Crumeyrolle, S., Gomes, L., Tulet, P., Matsuki, A., Schwarzenboeck, A., and Crahan, K.: Increase of the aerosol hygroscopicity by cloud processing in a mesoscale convective system: a case study from the AMMA campaign, Atmos. Chem. Phys., 8, 6907-6924, doi:10.5194/acp-8-6907-2008, 2008.

Csavina, J., Field, J., Taylor, M. P., Gao, S., Landazuri, A., Betterton, E. A., and Saez, A. E.: A review on the importance of metals and metalloids in atmospheric dust and aerosol from mining operations, Sci. Total Environ., 433, 58-73, 2012.

Cziczo, D. J., Murphy, D. M., Hudson, P. K., and Thomson, D. S.: Single particle measurements of the chemical composition of cirrus ice residue during CRYSTAL-FACE, J. Geophys. Res., 109, D04201, doi:10.1029/2003jd004032, 2004.

DeMott, P. J., Sassen, K., Poellot, M. R., Baumgardner, D., Rogers, D. C., Brooks, S. D., Prenni, A. J., and Kreidenweis, S. M.: African dust aerosols as atmospheric ice nuclei, Geophys. Res.
Lett., 30, 1732, doi:10.1029/2003g1017410, 2003a.

DeMott, P. J., Cziczo, D. J., Prenni, A. J., Murphy, D. M., Kreidenweis, S. M., Thomson, D. S., Borys, R., and Rogers, D. C.: Measurements of the concentration and composition of nuclei for cirrus formation, P. Natl. Acad. Sci. USA, 100, 14655-14660, doi:10.1073/pnas.2532677100, 2003b.

Desboeufs, K. V., Losno, R., and Colin, J. L.: Factors influencing aerosol solubility during cloud processes, Atmos. Environ., 35, 3529-3537, 2001.

Dias, V. R. D., Sanches, L., Alves, M. D., and Nogueira, J. D.: Spatio-temporal variability of anions in wet precipitation of Cuiaba, Brazil, Atmos. Res., 107, 9-19, 2012.

Draxler, R. R. and Rolph, G. D.: HYSPLIT (HYbrid Single-Particle Lagrangian Integrated Trajectory) Model access via NOAA ARL READY Website (http://ready.arl.noaa.gov/HYSPLIT. php); NOAA Air Resources Laboratory: Silver Spring, MD, 2012.

Drewnick, F., Schneider, J., Hings, S. S., Hock, N., Noone, K., Targino, A., Weimer, S., and Borrmann, S.: Measurement of ambient, interstitial, and residual aerosol particles on a mountaintop site in central Sweden using an aerosol mass spectrometer and a CVI, J. Atmos. Chem., 56, 1-20, 2007.

EANET: Second Periodic Report on the State of Acid Deposition in East Asia, Part III Executive Summary, Acid Deposition Monitoring Network in East Asia, http://www.eanet.asia/product/, 2011.

Environmental Protection Agency: Latest Findings on National Air Quality: 2002 Status and Trends, Office of Air Quality and Standards, Air Quality Strategies and Standards Division, Research Triangle Park, NC, 2003.

Fenn, M. E., Poth, M. A., Aber, J. D., Baron, J. S., Bormann, B. T., Johnson, D. W., Lemly, A. D., McNulty, S. G., Ryan, D. E., and Stottlemyer, R.: Nitrogen excess in North American ecosystems: Predisposing factors, ecosystem responses, and management strategies, Ecol. Appl., 8, 706-733, 1998.

Fenn, M. E., Baron, J. S., Allen, E. B., Rueth, H. M., Nydick, K. R., Geiser, L., Bowman, W. D., Sickman, J. O., Meixner, T., Johnson, D. W., and Neitlich, P.: Ecological effects of nitrogen deposition in the western United States, Bioscience, 53, 404-420, 2003.

Fernandez, D. P., Neff, J. C., and Reynolds, R. L.: Biogeochemical and ecological impacts of livestock grazing in semi-arid southeastern Utah, USA, J. Arid. Environ., 72, 777-791, 2008.

Galy-Lacaux, C., Laouali, D., Descroix, L., Gobron, N., and Liousse, C.: Long term precipitation chemistry and wet deposition in a remote dry savanna site in Africa (Niger), Atmos. Chem. Phys., 9, 1579-1595, doi:10.5194/acp-9-1579-2009, 2009.

Granat, L., Suksomsankh, K., Simachaya, S., Tabucanon, M., and Rodhe, R.: Regional background acidity and chemical composition of precipitation in Thailand, Atmos. Environ., 30, 15891596, 1996.

Harpold, A., Brooks, P., Rajagopal, S., Heidbuchel, I., Jardine, A., and Stielstra, C.: Changes in snowpack accumulation and ablation in the intermountain west, Water Resour. Res., 48, W11501, doi:10.1029/2012wr011949, 2012.

Hayden, K. L., Macdonald, A. M., Gong, W., Toom-Sauntry, D., Anlauf, K. G., Leithead, A., Li, S. M., Leaitch, W. R., and Noone, K.: Cloud processing of nitrate, J. Geophys. Res., 113, D18201, doi:10.1029/2007jd009732, 2008. 
Heintzenberg, J., Okada, K., and Strom, J.: On the composition of non-volatile material in upper tropospheric aerosols and cirrus crystals, Atmos. Res., 41, 81-88, 1996.

Herrera, J., Rodriguez, S., and Baez, A. P.: Chemical composition of bulk precipitation in the metropolitan area of Costa Rica, Central America, Atmos. Res., 94, 151-160, 2009.

Herut, B., Starinsky, A., Katz, A., and Rosenfeld, D.: Relationship between the acidity and chemical composition of rainwater and climatological conditions along a transition zone between large deserts and Mediterranean climate, Israel, Atmos. Environ., 34, 1281-1292, 2000.

Higgins, R. W., Yao, Y., and Wang, X. L.: Influence of the North American monsoon system on the US summer precipitation regime, J. Climate, 10, 2600-2622, 1997.

Hou, S. G., Qin, D. H., Zhang, D. Q., Kang, S. C., Mayewski, P. A., and Wake, C. P.: A 154a high-resolution ammonium record from the Rongbuk Glacier, north slope of Mt. Qomolangma (Everest), Tibet-Himal region, Atmos. Environ., 37, 721-729, 2003.

Hsu, N. C., Herman, J. R., Torres, O., Holben, B. N., Tanre, D., Eck, T. F., Smirnov, A., Chatenet, B., and Lavenu, F.: Comparisons of the TOMS aerosol index with Sun-photometer aerosol optical thickness: Results and applications, J. Geophys. Res., 104, 62696279, doi:10.1029/1998jd200086, 1999.

Hutchings, J. W., Robinson, M. S., McIlwraith, H., Kingston, J. T., and Herckes, P.: The chemistry of intercepted clouds in northern Arizona during the North American Monsoon Season, Water Air Soil Poll., 199, 191-202, 2009.

Isono, K. and Ikebe, Y.: On the ice-nucleating ability of rockforming minerals and soil particles, J. Meteorol. Soc. Jpn., 38, 213-230, 1960.

Izquierdo, R., Avila, A., and Alarcon, M.: Trajectory statistical analysis of atmospheric transport patterns and trends in precipitation chemistry of a rural site in NE Spain in 1984-2009, Atmos. Environ., 61, 400-408, doi:10.1016/j.atmosenv.2012.07.060, 2012.

Jacobi, H. W., Voisin, D., Jaffrezo, J. L., Cozic, J., and Douglas, T. A.: Chemical composition of the snowpack during the OASIS spring campaign 2009 at Barrow, Alaska, J. Geophys. Res., 117, D00r13, doi:10.1029/2011jd016654, 2012.

Jaffe, D., Snow, J., and Cooper, O.: The 2001 Asian dust events: Transport and impact on surface aerosol concentrations in the U.S., EOS Trans. AGU, 84, 501-516, 2003.

Johnson, B. J., Huang, S. C., Lecave, M., and Porterfield, M.: Seasonal trends of nitric-acid, particulate nitrate, and particulate sulfate concentrations at a southwestern United-States mountain site, Atmos. Environ., 28, 1175-1179, 1994.

Kang, S. C., Mayewski, P. A., Qin, D. H., Yan, Y. P., Zhang, D. Q., Hou, S. G., and Ren, J. W.: Twentieth century increase of atmospheric ammonia recorded in Mount Everest ice core, J. Geophys. Res., 107, 4595, doi:10.1029/2001jd001413, 2002.

Kavouras, I. G., Etyemezian, V., DuBois, D. W., Xu, J., and Pitchford, M.: Source reconciliation of atmospheric dust causing visibility impairment in Class I areas of the western United States, J. Geophys. Res., 114, D02308, doi:10.1029/2008jd009923, 2009.

Khemani, L. T., Momin, G. A., Naik, M. S., Rao, P. S. P., Safai, P. D., and Murty, A. S. R.: Influence of alkaline particulates on ph of cloud and rain water in India, Atmos. Environ., 21, 11371145, 1987.

Kleeman, M. J., Hughes, L. S., Allen, J. O., and Cass, G. R.: Source contributions to the size and composition distribution of atmo- spheric particles: Southern California in September 1996, Environ. Sci. Technol., 33, 4331-4341, 1999.

Koehler, K. A., Kreidenweis, S. M., DeMott, P. J., Prenni, A. J., and Petters, M. D.: Potential impact of Owens (dry) Lake dust on warm and cold cloud formation, J. Geophys. Res., 112, D12210, doi:10.1029/2007jd008413, 2007.

Kreutz, K. J., Aizen, V. B., Cecil, L. D., and Wake, C. P.: Oxygen isotopic and soluble ionic composition of a shallow firn core, Inilchek glacier, central Tien Shan, J. Glaciol., 47, 548-554, 2001.

Kulshrestha, U. C., Granat, L., Engardt, M., and Rodhe, H.: Review of precipitation monitoring studies in India-a search for region patterns, Atmos. Environ., 39, 7403-7419, 2005.

Kumai, M.: Snow crystals and the identification of the nuclei in the northern United-States of America, J. Meteorol., 18, 139-150, 1961.

Kvale, K. F. and Pryor, S. C.: Precipitation composition in the Ohio River Valley: Spatial variability and temporal trends, Water Air Soil Poll., 170, 143-160, doi:10.1007/s11270-006-2861-1, 2006.

Landers, D. H., Eilers, J. M., Brakke, D. F., Overton, W. S., Kellar, P. E., Silverstein, M. E., Schonbrod, M. E., Crowe, R. D., Linthurst, R. E., Omernik, J. M., Teague, S. A., and Meier, E. P.: Western Lake Survey Phase I, characteristics of lakes in the western United States, Volume I: population description and physicochemical relationships. Washington, DC, US Environmental Protection Agency, EPA/600/3-86/054a, 176 pp., 1987.

Lawrence, C. R. and Neff, J. C.: The contemporary physical and chemical flux of aeolian dust: A synthesis of direct measurements of dust deposition, Chem. Geol., 267, 46-63, 2009.

Lee, T., Kreidenweis, S. M., and Collett, J. L.: Aerosol ion characteristics during the Big Bend Regional Aerosol and Visibility Observational Study, J. Air Waste Manage., 54, 585-592, 2004.

Lee, T., Yu, X. Y., Ayres, B., Kreidenweis, S. M., Malm, W. C., and Collett, J. L.: Observations of fine and coarse particle nitrate at several rural locations in the United States, Atmos. Environ., 42, 2720-2732, 2008.

Legrand, M. and Mayewski, P.: Glaciochemistry of polar ice cores: A review, Rev. Geophys., 35, 219-243, 1997.

Lehmann, C. M. B. and Gay, D. A.: Monitoring long-term trends of acidic wet deposition in US precipitation: Results from the National Atmospheric Deposition Program, PowerPlant Chemistry, $13,2011$.

Lehmann, C. M. B., Bowersox, V. C., and Larson, S. M.: Spatial and temporal trends of precipitation chemistry in the United States, 1985-2002, Environ. Pollut., 135, 347-361, doi:10.1016/j.envpol.2004.11.016, 2005.

Levin, Z., Ganor, E., and Gladstein, V.: The effects of desert particles coated with sulfate on rain formation in the eastern Mediterranean, J. Appl. Meteorol., 35, 1511-1523, 1996.

Likens, G.: Acid rain, in: Environmental Information Coalition, edited by: Cleveland, C. J., National Council for Science and the Environment, Encyclopedia of Earth, Washington, DC, http:// www.eoearth.org/article/Acid_rain, (last access: February 2013), 2007.

Liptzin, D. and Seastedt, T. R.: Regional and local patterns of soil nutrients at Rocky Mountain treelines, Geoderma, 160, 208-217, 2010.

Loye-Pilot, M. D. and Morelli, J.: Fluctuations of ionic composition of precipitations collected in corsica related to changes in the origins of incoming aerosols, J. Aerosol Sci., 19, 577-585, 1988. 
Lynch, J. A., Grimm, J. W., and Bowersox, V. C.: Trends in precipitation chemistry in the United-States - a national perspective, 1980-1992, Atmos. Environ., 29, 1231-1246, doi:10.1016/13522310(94)00371-Q, 1995.

Mahowald, N., Jickells, T. D., Baker, A. R., Artaxo, P., BenitezNelson, C. R., Bergametti, G., Bond, T. C., Chen, Y., Cohen, D. D., Herut, B., Kubilay, N., Losno, R., Luo, C., Maenhaut, W., McGee, K. A., Okin, G. S., Siefert, R. L., and Tsukuda, S.: Global distribution of atmospheric phosphorus sources, concentrations and deposition rates, and anthropogenic impacts, Global Biogeochem. Cy., 22, Gb4026, doi:10.1029/2008gb003240, 2008.

Malm, W. C., Sisler, J. F., Huffman, D., Eldred, R. A., and Cahill, T. A.: Spatial and Seasonal Trends in Particle Concentration and Optical Extinction in the United-States, J. Geophys. Res., 99, 1347-1370, doi:10.1029/93jd02916, 1994.

Malm, W. C., Day, D. E., Kreidenweis, S. M., Collett, J. L., and Lee, T.: Humidity-dependent optical properties of fine particles during the Big Bend regional aerosol and visibility observational study, J. Geophys. Res., 108, 4279, doi:10.1029/2002jd002998, 2003.

Malm, W. C., Schichtel, B. A., Pitchford, M. L., Ashbaugh, L. L., and Eldred, R. A.: Spatial and monthly trends in speciated fine particle concentration in the United States, J. Geophys. Res., 109, D03306, doi:10.1029/2003jd003739, 2004.

Matichuk, R., Barbaris, B., Betterton, E. A., Hori, M., Murao, N., Ohta, S., and Ward, D.: A decade of aerosol and gas precursor chemical characterization at Mt. Lemmon, Arizona (1992 to 2002), J. Meteorol. Soc. Jpn., 84, 653-670, 2006.

Matsuki, A., Schwarzenboeck, A., Venzac, H., Laj, P., Crumeyrolle, S., and Gomes, L.: Cloud processing of mineral dust: direct comparison of cloud residual and clear sky particles during AMMA aircraft campaign in summer 2006, Atmos. Chem. Phys., 10, 1057-1069, doi:10.5194/acp-10-1057-2010, 2010.

Migliavacca, D., Teixeira, E. C., Pires, M., and Fachel, J.: Study of chemical elements in atmospheric precipitation in South Brazil, Atmos. Environ., 38, 1641-1656, 2004.

Migliavacca, D., Teixeira, E. C., Wiegand, F., Machado, A. C. M., and Sanchez, J.: Atmospheric precipitation and chemical composition of an urban site, Guaiba hydrographic basin, Brazil, Atmos. Environ., 39, 1829-1844, 2005.

Morales-Baquero, R., Pulido-Villena, E., and Reche, I.: Atmospheric inputs of phosphorus and nitrogen to the southwest Mediterranean region: Biogeochemical responses of high mountain lakes, Limnol. Oceanogr., 51, 830-837, 2006.

Mouli, P. C., Mohan, S. V., and Reddy, S. J.: Rainwater chemistry at a regional representative urban site: influence of terrestrial sources on ionic composition, Atmos. Environ., 39, 999-1008, 2005.

Neff, J. C., Reynolds, R. L., Belnap, J., and Lamothe, P.: Multidecadal impacts of grazing on soil physical and biogeochemical properties in southeast Utah, Ecol. Appl., 15, 87-95, 2005.

Neff, J. C., Ballantyne, A. P., Farmer, G. L., Mahowald, N. M., Conroy, J. L., Landry, C. C., Overpeck, J. T., Painter, T. H., Lawrence, C. R., and Reynolds, R. L.: Increasing eolian dust deposition in the western United States linked to human activity, Nat. Geosci., 1, 189-195, 2008.

Nilles, M. A. and Conley, B. E.: Changes in the chemistry of precipitation in the United States, 1981-1998, Water Air Soil Poll.,
130, 409-414, doi:10.1023/A:1013889302895, 2001.

Okin, G. S., Mahowald, N., Chadwick, O. A., and Artaxo, P.: Impact of desert dust on the biogeochemistry of phosphorus in terrestrial ecosystems, Global Biogeochem. Cy., 18, Gb2005, doi:10.1029/2003gb002145, 2004.

Olivier, S., Blaser, C., Brutsch, S., Frolova, N., Gaggeler, H. W., Henderson, K. A., Palmer, A. S., Papina, T., and Schwikowski, M.: Temporal variations of mineral dust, biogenic tracers, and anthropogenic species during the past two centuries from Belukha ice core, Siberian Altai, J. Geophys. Res., 111, D05309, doi:10.1029/2005jd005830, 2006.

Painter, T. H., Barrett, A. P., Landry, C. C., Neff, J. C., Cassidy, M. P., Lawrence, C. R., McBride, K. E., and Farmer, G. L.: Impact of disturbed desert soils on duration of mountain snow cover, Geophys. Res. Lett., 34, L12502, doi:10.1029/2007gl030284, 2007.

Painter, T. H., Deems, J. S., Belnap, J., Hamlet, A. F., Landry, C. C., and Udall, B.: Response of Colorado River runoff to dust radiative forcing in snow, P. Natl. Acad. Sci. USA, 107, 1712517130, doi:10.1073/pnas.0913139107, 2010.

Prenni, A. J., Petters, M. D., Kreidenweis, S. M., Heald, C. L., Martin, S. T., Artaxo, P., Garland, R. M., Wollny, A. G., and Pöschl, U.: Relative roles of biogenic emissions and Saharan dust as ice nuclei in the Amazon basin, Nat. Geosci., 2, 401-404, 2009.

Preunkert, S., Wagenbach, D., and Legrand, M.: A seasonally resolved alpine ice core record of nitrate: Comparison with anthropogenic inventories and estimation of preindustrial emissions of NO in Europe, J. Geophys. Res., 108, 4681, doi:10.1029/2003jd003475, 2003.

Psenner, R.: Living in a dusty world: Airborne dust as a key factor for alpine lakes, Water Air Soil Poll., 112, 217-227, 1999.

Qin, G. Y. and Huang, M. Y.: A study on rain acidification processes in ten cities of China, Water Air Soil Poll., 130, 163-174, 2001.

Raman, R. S. and Ramachandran, S.: Source apportionment of the ionic components in precipitation over an urban region in Western India, Environ. Sci. Pollut. R., 18, 212-225, 2011.

Reynolds, R., Belnap, J., Reheis, M., Lamothe, P., and Luiszer, F.: Aeolian dust in Colorado Plateau soils: Nutrient inputs and recent change in source, P. Natl. Acad. Sci. USA, 98, 7123-7127, 2001.

Rhoades, C., Elder, K., and Greene, E.: The influence of an extensive dust event on snow chemistry in the Southern Rocky Mountains, Arct. Antarct. Alp. Res., 42, 98-105, 2010.

Rosenfeld, D. and Givati, A.: Evidence of orographic precipitation suppression by air pollution-induced aerosols in the western United States, J. Appl. Meteorol. Clim., 45, 893-911, 2006.

Rosenfeld, D., Rudich, Y., and Lahav, R.: Desert dust suppressing precipitation: A possible desertification feedback loop, P. Natl. Acad. Sci. USA, 98, 5975-5980, 2001.

Safai, P. D., Rao, P. S. P., Mornin, G. A., All, K., Chate, D. M., and Praveen, P. S.: Chemical composition of precipitation during 1984-2002 at Pune, India, Atmos. Environ., 38, 1705-1714, 2004.

Sassen, K., DeMott, P. J., Prospero, J. M., and Poellot, M. R.: Saharan dust storms and indirect aerosol effects on clouds: CRYSTAL-FACE results, Geophys. Res. Lett., 30, 1633, doi:10.1029/2003g1017371, 2003.

Satyanarayana, J., Reddy, L. A. K., Kulshrestha, M. J., Rao, R. N., and Kulshrestha, U. C.: Chemical composition of rain water and influence of airmass trajectories at a rural site in an ecological 
sensitive area of Western Ghats (India), J. Atmos. Chem., 66, 101-116, doi:10.1007/s10874-011-9193-2, 2010.

Schichtel, B. A., Malm, W. C., Bench, G., Fallon, S., McDade, C. E., Chow, J. C., and Watson, J. G.: Fossil and contemporary fine particulate carbon fractions at 12 rural and urban sites in the United States, J. Geophys. Res., 113, D02311, doi:10.1029/2007jd008605, 2008.

Schlesinger, W. H., Reynolds, J. F., Cunningham, G. L., Huenneke, L. F., Jarrell, W. M., Virginia, R. A., and Whitford, W. G.: Biological feedbacks in global desertification, Science, 247, 10431048, 1990.

Schwikowski, M., Seibert, P., Baltensperger, U., and Gaggeler, H. W.: A study of an outstanding saharan dust event at the high-alpine site Jungfraujoch, Switzerland, Atmos. Environ., 29, 1829-1842, 1995.

Schwikowski, M., Doscher, A., Gaggeler, H. W., and Schotterer, U.: Anthropogenic versus natural sources of atmospheric sulphate from an Alpine ice core, Tellus B, 51, 938-951, 1999.

Seager, R. and Vecchi, G. A.: Greenhouse warming and the 21 st century hydroclimate of southwestern North America, P. Natl. Acad. Sci. USA, 107, 21277-21282, doi:10.1073/pnas.0910856107, 2010.

Seinfeld, J. H. and Pandis, S. N.: Atmospheric Chemistry and Physics, Second Edition, Wiley-Interscience, New York, 2006.

Singh, K. P., Singh, V. K., Malik, A., Sharma, N., Murthy, R. C., and Kumar, R.: Hydrochemistry of wet atmospheric precipitation over an urban area in northern Indo-gangetic plains, Environ. Monit. Assess., 131, 237-254, 2007.

Sirois, A., Vet, R., and Lamb, D.: A comparison of the precipitation chemistry measurements obtained by the CAPMoN and NADP/NTN networks, Environ. Monit. Assess., 62, 273-303, doi:10.1023/A:1006272609744, 2000.

Skiles, S. M., Painter, T. H., Deems, J. S., Bryant, A. C., and Landry, C. C.: Dust radiative forcing in snow of the Upper Colorado River Basin: 2. Interannual variability in radiative forcing and snowmelt rates, Water Resour. Res., 48, W07522, doi:10.1029/2012wr011986, 2012.

Sorooshian, A., Murphy, S. M., Hersey, S., Gates, H., Padro, L. T., Nenes, A., Brechtel, F. J., Jonsson, H., Flagan, R. C., and Seinfeld, J. H.: Comprehensive airborne characterization of aerosol from a major bovine source, Atmos. Chem. Phys., 8, 5489-5520, doi:10.5194/acp-8-5489-2008, 2008.

Sorooshian, A., Wonaschütz, A., Jarjour, E. G., Hashimoto, B. I., Schichtel, B. A., and Betterton, E. A.: An aerosol climatology for a rapidly growing arid region (southern Arizona): Major aerosol species and remotely sensed aerosol properties, J. Geophys. Res., 116, 19205, doi:10.1029/2011jd016197, 2011.

Sorooshian, A., Csavina, J., Shingler, T., Dey, S., Brechtel, F. J., Saez, A. E., and Betterton, E. A.: Hygroscopic and chemical properties of aerosols collected near a copper smelter: implications for public and environmental health, Environ. Sci. Technol., 46, 9473-9480, 2012.

Stoorvogel, J. J., VanBreemen, N., and Janssen, B. H.: The nutrient input by Harmattan dust to a forest ecosystem in Cote d'Ivoire, Africa, Biogeochemistry, 37, 145-157, 1997.

Sullivan, R. C., Guazzotti, S. A., Sodeman, D. A., and Prather, K. A.: Direct observations of the atmospheric processing of Asian mineral dust, Atmos. Chem. Phys., 7, 1213-1236, doi:10.5194/acp-7-1213-2007, 2007.
Teixeira, E. C., Migliavacca, D., Pereira, S., Machado, A. C. M., and Dallarosa, J. B.: Study of wet precipitation and its chemical composition in South of Brazil, An. Acad. Bras. Cienc., 80, 381395, 2008.

Tong, D. Q., Dan, M., Wang, T., and Lee, P.: Long-term dust climatology in the western United States reconstructed from routine aerosol ground monitoring, Atmos. Chem. Phys., 12, 5189-5205, doi:10.5194/acp-12-5189-2012, 2012.

Topcu, S., Incecik, S., and Atimtay, A. T.: Chemical composition of rainwater at EMEP station in Ankara, Turkey, Atmos. Res., 65, 77-92, 2002.

Torres, O., Bhartia, P. K., Herman, J. R., Ahmad, Z., and Gleason, J.: Derivation of aerosol properties from satellite measurements of backscattered ultraviolet radiation: Theoretical basis, J. Geophys. Res., 103, 17099-17110, 1998.

Turk, J. T., Taylor, H. E., Ingersoll, G. P., Tonnessen, K. A., Clow, D. W., Mast, M. A., Campbell, D. H., and Melack, J. M.: Majorion chemistry of the Rocky Mountain snowpack, USA, Atmos. Environ., 35, 3957-3966, 2001.

Twohy, C. H. and Gandrud, B. W.: Electron microscope analysis of residual particles from aircraft contrails, Geophys. Res. Lett., 25, 1359-1362, 1998.

United States Census Bureau: http://www.census.gov/popest/data/ index.html, 2010.

VanCuren, R. A. and Cahill, T. A.: Asian aerosols in North America: Frequency and concentration of fine dust, J. Geophys. Res., 107, 4804, doi:10.1029/2002jd002204, 2002.

van der Swaluw, E., Asman, W. A. H., van Jaarsveld, H., and Hoogerbrugge, R.: Wet deposition of ammonium, nitrate and sulfate in the Netherlands over the period 1992-2008, Atmos. Environ., 45, 3819-3826, 2011.

Vicars, W. C. and Sickman, J. O.: Mineral dust transport to the Sierra Nevada, California: Loading rates and potential source areas, J. Geophys. Res., 116, G01018, doi:10.1029/2010jg001394, 2011.

Wake, C. P., Mayewski, P. A., and Spencer, M. J.: A review of central Asian glaciochemical data, Ann. Glaciol., 14, 301-306, 1990.

Wake, C. P., Mayewski, P. A., Wang, P., Yang, Q. H., Han, J. K., and Xie, Z. H.: Anthropogenic sulfate and Asian dust signals in snow from Tien-Shan, northwest China, Ann. Glaciol., 16, 4552, 1992.

Wells, K. C., Witek, M., Flatau, P., Kreidenweis, S. M., and Westphal, D. L.: An analysis of seasonal surface dust aerosol concentrations in the western US (2001-2004): Observations and model predictions, Atmos. Environ., 41, 6585-6597, 2007.

Williams, M. W. and Melack, J. M.: Solute chemistry of snowmelt and runoff in an alpine basin, Sierra-Nevada, Water Resour. Res., 27, 1575-1588, 1991.

Wolfe, A. P., Van Gorp, A. C., and Baron, J. S.: Recent ecological and biogeochemical changes in alpine lakes of Rocky Mountain National Park (Colorado, USA): a response to anthropogenic nitrogen deposition, Geobiology, 1, 153-168, 2003.

Wonaschütz, A., Hersey, S. P., Sorooshian, A., Craven, J. S., Metcalf, A. R., Flagan, R. C., and Seinfeld, J. H.: Impact of a large wildfire on water-soluble organic aerosol in a major urban area: the 2009 Station Fire in Los Angeles County, Atmos. Chem. Phys., 11, 8257-8270, doi:10.5194/acp-11-8257-2011, 2011. 
Woodhouse, C. A., Meko, D. M., MacDonald, G. M., Stahle, D. W., and Cooke, E. R.: A 1,200-year perspective of 21st century drought in southwestern North America, P. Natl. Acad. Sci. USA, 107, 21283-21288, doi:10.1073/pnas.0911197107, 2010.

Yeung, M. C., Lee, S. C., Lun, B. H., and Tanner, P. A.: Summer rain events in south-east Asia: Spatial and temporal variations, Atmos. Res., 86, 241-248, 2007.

Yi, L., Xiaolan, Y., Hongbing, C., Weili, L., Jie, T., and Shufeng, W.: Chemical characteristics of precipitation at three Chinese regional background stations from 2006 to 2007, Atmos. Res., 96, 173-183, 2010.

Youn, J.-S., Wang, Z., Wonaschütz, A., Arellano, A., Betterton, E. A., and Sorooshian, A.: Evidence of aqueous secondary organic aerosol formation from biogenic emissions in the North American Sonoran Desert, Geophys. Res. Lett., 40, 3468-3472, doi:10.1002/grl.50644, 2013.

Yu, X. Y., Taehyoung, L., Ayres, B., Kreidenweis, S. M., Collett, J. L., and Malm, W.: Particulate nitrate measurement using nylon filters, J. Air Waste Manage., 55, 1100-1110, 2005.
Zhang, M. Y., Wang, S. J., Wu, F. C., Yuan, X. H., and Zhang, Y.: Chemical compositions of wet precipitation and anthropogenic influences at a developing urban site in southeastern China, Atmos. Res., 84, 311-322, 2007.

Zhang, Y. L., Kang, S. C., Li, C. L., Cong, Z. Y., and Zhang, Q. G.: Wet deposition of precipitation chemistry during 2005-2009 at a remote site (Nam Co Station) in central Tibetan Plateau, J. Atmos. Chem., 69, 187-200, 2012.

Zhao, H. B., Xu, B. Q., Yao, T. D., Tian, L. D., and Li, Z.: Records of sulfate and nitrate in an ice core from Mount Muztagata, central Asia, J. Geophys. Res., 116, D13304, doi:10.1029/2011jd015735, 2011.

Zimmermann, F., Weinbruch, S., Schutz, L., Hofmann, H., Ebert, M., Kandler, K., and Worringen, A.: Ice nucleation properties of the most abundant mineral dust phases, J. Geophys. Res., 113, D23204, doi:10.1029/2008jd010655, 2008. 